\author{
Revista Brasileira de Educação do Campo \\ Brazilian Journal of Rural Education \\ ARTIGO/ARTICLE/ARTÍCULO \\ DOI: $\underline{\text { http://dx.doi.org/10.20873/uft.rbec.e12965 }}$
}

\title{
A práxis de egressos(os) da LEdoC UnB na gestão das escolas do campo: caminhos para resistência à Matriz Nacional Comum de Competências do Diretor Escolar
}

Mônica Castagna Molina ${ }^{1}$, iD Marcelo Fabiano Rodrigues Pereira ${ }^{2}$, iD Márcia Mariana Bittencourt Brito ${ }^{3}$

${ }^{1}$ Universidade de Brasília - UnB. Programa de Pós-Graduação em Educação. Campus UnB Planaltina. Área Universitária, 01 , Vila Nossa Senhora de Fátima. Planaltina - DF. Brasil. ${ }^{2}$ Secretaria de Estado de Educação do Distrito Federal. ${ }^{3}$ Universidade Federal do Pará - UFPA.

Autor para correspondência/Author for correspondence: mcastagnamolina@gmail.com

\begin{abstract}
RESUMO. As reflexões aqui apresentadas integram uma pesquisa desenvolvida com o apoio do CNPq - Conselho Nacional de Desenvolvimento Científico e Tecnológico objetivando analisar a práxis de egressos(os) da Licenciatura em Educação do Campo da Universidade de Brasília - LEdoC UnB e suas contribuições na implementação de novas lógicas de Organização Escolar e do Trabalho Pedagógico nas Escolas do Campo, com realização entre 2020 e 2023. Neste artigo problematiza-se a proposição do Conselho Nacional de Educação - CNE em estabelecer uma Matriz Nacional Comum de Competências do Diretor Escolar - MNCCDE e busca-se essa discussão com base na perspectiva dos princípios da Educação do Campo que orientam o projeto formativo das LEdoCs. O objetivo central deste texto é identificar os caminhos e possibilidades da atuação dos(as) egressos(as) da LEdoC UnB que sinalizam resistência à perspectiva neoliberal, neotecnicista e gerencialista de secundarizar o princípio da gestão democrática. A orientação metodológica ancora-se nos pressupostos do Materialismo Histórico-dialético, tendo como categorias centrais a totalidade, a historicidade e a contradição. Os sujeitos colaboradores da pesquisa são egressos(as) da LEdoC da Universidade de Brasília que atuam ou atuaram na gestão de processos educativos escolares. Nesse sentido, foram realizadas rodas de conversa com os referidos sujeitos e análise documental dos seguintes materiais: Projetos Políticos Pedagógicos das escolas nas quais os(as) egressos(as) atuam ou atuaram; Dissertações e Trabalhos de Conclusão de Curso e produzidos por eles e análise da Minuta da MNCCDE. Os resultados apontam que essa Matriz atenta contra os princípios pedagógicos que vêm sendo trabalhados nos cursos de Licenciatura em Educação do Campo no Brasil e a práxis dos(as) egressos(as) da LEdoC UnB colaboradores(as) da pesquisa sinalizam resistências ao projeto educativo do capital em diferentes dimensões, destacando-se a) a busca pela intrínseca articulação entre as lutas pelo direito à terra, ao trabalho e à educação compromisso político; b) a unidade Teoria-Prática na perspectiva da práxis; c) o trabalho coletivo e a participação da comunidade; d) a auto-organização e f) o exercício da gestão democrática fundada na compreensão da democracia participativa a partir da autogestão.
\end{abstract}

Palavras-chave: Educação do Campo, práxis, egressos(as), gestão democrática.

\begin{tabular}{|l|l|l|l|l|l|l|} 
RBEC & Tocantinópolis/Brasil & v. 6 & e12965 & $10.20873 /$ uft.rbec.e12965 & 2021 & ISSN: 2525-4863 \\
\hline
\end{tabular}




\title{
The praxis of the graduates in Education for Rural Area Course of the University of Brasilia in the management of rural schools: pathways of resistance to the
}

\begin{abstract}
The reflections presented here are part of a research developed with the support of the National Council of Scientific and Technological Development (CNPq), aiming at analyzing the praxis of graduates of the Licentiate Degree in Education for Rural Areas of the University of Brasília LEdoC UnB and their contributions to the implementation of new logics of School Organization and Pedagogical Work in Schools for Rural Areas, held between 2020 and 2023. This article discusses the proposition of the National Council of Education - CNE to establish a Common National Competence Matrix for School Principal - MNCCDE and seeks this discussion based on the perspective of the Education for Rural Areas principles that guide the training project of the LEDoCs. The main objective of this text is to identify the ways and possibilities of action of LEdoC UnB graduates that points to resistance to the neoliberal, neotechnicist and generalizing perspective of making the principle of democratic management secondary. The methodological orientation is anchored in the assumptions of Historicaldialectical Materialism, having totality, historicity and contradiction as central categories. The collaborating subjects of the research are graduates of LEdoC of the University of Brasília who work or have worked in the management of school educational processes. In this sense, conversation circles were held with the referred subjects and documental analysis of the following materials was made: Pedagogical Political Projects of the schools in which the graduates work or have worked; Course Conclusion papers and Dissertations produced by them and analysis of the MNCCDE Draft. The results show that this Matrix attacks the pedagogical principles that have been worked in the Licentiate Courses in Education for rural Areas in Brazil and that the praxis of LEdoC UnB alumni who collaborated to this research points to resistance to the capital's educational project in different dimensions, highlighting: a) the search for the intrinsic articulation between the struggles for the right to land, work and education - political commitment; b) the Theory-Practice unit from the perspective of praxis; c) collective work and community participation; d) self-organization and f) the exercise of democratic management based on the understanding of participatory democracy based on self-management.
\end{abstract}

Keywords: Education for Rural Areas, praxis, graduates, democratic management. 


\section{La praxis de los egresados de la Licenciatura en Educación de Campo de la Universidad de Brasilia en la gestión de escuelas de campo: vías de resistencia a la Matriz Común Nacional de Competencias para el Director Escolar}

RESUMEN. Las reflexiones aquí presentadas son parte de una investigación desarrollada con el apoyo del Consejo Nacional de Desarrollo Científico y Tecnológico - CNPq, con el objetivo de analizar la praxis de los egresados de la Licenciatura en Educación de Campo de la Universidad de Brasilia LEdoC UnB y sus contribuciones a la implementación de nuevas lógicas de Organización Escolar y Trabajo Pedagógico en Escuelas de campo, realizada entre 2020 y 2023. Este artículo analiza la propuesta del Consejo Nacional de Educación - CNE de establecer una Matriz Común Nacional de Competencias para el Director Escolar - MNCCDE y busca esta discusión basada en la perspectiva de los principios de Educación de Campo que orientan el proyecto de formación de las LEDoC. El objetivo principal de este texto es identificar las formas y posibilidades de acción de los egresados de LEdoC UnB que señalan la resistencia a la perspectiva neoliberal, neotécnica y gerencial de hacer secundario el principio de gestión democrática. La orientación metodológica se ancla en los supuestos del materialismo histórico-dialéctico, teniendo como categorías centrales la totalidad, la historicidad y la contradicción. Los sujetos colaboradores de la investigación son egresados de LEdoC de la Universidad de Brasilia que trabajan o han actuado en la gestión de procesos educativos escolares. En este sentido, se realizaron círculos de conversación con los temas referidos y análisis documental de los siguientes materiales: Proyectos Políticos Pedagógicos de las escuelas en las que trabajan o han trabajado los egresados; Trabajos de Conclusión del Curso y Disertaciones elaborados por ellos y análisis del Borrador del MNCCDE. Los resultados muestran que esta Matriz ataca los principios pedagógicos que se han trabajado en los cursos de Licenciatura en Educación de Campo en Brasil y que la praxis de egresados de LEdoC UnB, colaboradores de investigación, señala resistencias al proyecto educativo del capital en diferentes dimensiones, con énfasis en: a) la búsqueda de la articulación intrínseca entre las luchas por el derecho a la tierra, el trabajo y la educación - compromiso político; b) la unidad TeoríaPráctica desde la perspectiva de la praxis; c) trabajo colectivo y participación comunitaria; d) la autoorganización y f) el ejercicio de una gestión democrática basada en la comprensión de la democracia participativa basada en la autogestión.

Palabras clave: Educación de campo, praxis, egresados, gestión democrática. 


\section{Introdução}

As reflexões aqui apresentadas são desdobramentos de uma pesquisa que objetiva analisar a práxis dos egressos(as) da Licenciatura em Educação do Campo da Universidade de Brasília - LEdoC UnB. Esta pesquisa, com realização entre 2020 e 2023, é desenvolvida com o apoio do $\mathrm{CNPq}-$ Conselho Nacional de Desenvolvimento Científico e Tecnológico e pretende identificar as contribuições que a práxis desses egressos(as) traz para a implementação de novas lógicas de Organização Escolar e do Trabalho Pedagógico nas escolas do campo.

No presente texto, apresenta-se uma parte dos resultados da pesquisa problematizando a Minuta de Resolução MEC/CNE (2021), que propõe uma Matriz Nacional Comum de Competência do Diretor Escolar - MNCCDE, contrapondoa com os Princípios da Educação do Campo que orientam o projeto formativo das Licenciaturas em Educação do Campo, de modo específico à ofertada pela Universidade de Brasília. Com essa finalidade, este texto analisa a práxis de egressos(as) da LEdoC UnB materializada em suas intencionalidades na atuação em Gestão de Processos Educativos Escolares em Cárceres e Tangará da Serra, Mato Grosso, e no Território Calunga, Goiás.
A referida minuta foi exposta a Consulta Pública pelo Conselho Nacional de Educação a partir de fevereiro de 2021. O documento, inspirado em experiências em curso em outros países, apresenta uma matriz com dez competências gerais e dezessete competências específicas do Diretor Escolar, distribuídas em quatro eixos: político-institucional, pedagógico, administrativo-financeiro, pessoal/relacional.

Com o objetivo de levantar caminhos e possibilidades de resistência a essa Matriz, optou-se por analisar a atuação dos(as) egressos(as) dessa Licenciatura da Universidade de Brasília, que sinaliza oposição à perspectiva neoliberal, neotecnicista e gerencialista de secundarizar o princípio da gestão democrática. Para essa análise, recorreu-se aos princípios do Materialismo Históricodialético, por se perceber em suas categorias, sobretudo historicidade, totalidade e contradições, elementos que permitem a interpretação da realidade considerando as relações sociais que envolvem a gestão escolar como fenômenos sociais totais.

Nessa direção, realizou-se a análise documental da Matriz Nacional Comum de Competências do Diretor Escolar. Foram também analisados Projetos Políticos Pedagógicos das escolas nas quais os 
egressos atuam ou atuaram, além de Trabalhos de Conclusão de Curso e Dissertações de Mestrado produzidos pelos sujeitos da pesquisa. Por meio de rodas de conversa, foram entrevistados três egressos do curso, sendo duas mulheres que já assumiram a gestão escolar em suas comunidades, eleitas para duas gestões consecutivas, e um egresso que, no corrente ano, ainda atua na gestão de processos educativos no território do Quilombo Kalunga.

É importante destacar que a produção do conhecimento a partir da execução das Licenciaturas em Educação do Campo vem sendo objeto de pesquisa há mais de uma década (Molina, AntunesRocha, \& Martins, 2019), buscando acompanhar os relevantes avanços produzidos por essa política de formação docente como parte da própria luta da classe trabalhadora, não só pela construção de um projeto de campo, mas, sobretudo por um outro projeto societário que supere a lógica da sociedade capitalista.

Cumpre ressaltar, em relação à produção do conhecimento sobre a Licenciatura em Educação do Campo e sobre seus egressos, que vem sendo feito um esforço coletivo para priorizar e estimular essa produção pelos próprios sujeitos coletivos do campo tanto durante a Licenciatura quanto depois dela, com a sua inserção em mestrados e doutorados, a fim de que eles próprios registrem os processos formativos de que participam e ações que protagonizam nas comunidades e escolas camponesas.

$$
\text { Molina (2017) afirma que a }
$$
concepção educativa contida nas Licenciaturas em Educação do Campo se materializa intrinsecamente vinculada à luta de classes no campo brasileiro, colocando-se como parte e ao lado do polo do trabalho, assumindo e defendendo a educação como um direito e um bem público e social. Porém, a perspectiva da educação como um direito e um bem público e social está sendo alvo de grandes ataques, especialmente nas últimas décadas, pela atuação dos representantes dos interesses do capital, que buscam disseminar os princípios de uma "nova pedagogia da hegemonia" (Neves, 2005).

Essa nova pedagogia da hegemonia, acentuada no momento histórico atual do Brasil, vem-se intensificando desde os anos 1990 com influxos na organização do trabalho e do Estado, revelando seu caráter monopolista em nível nacional e internacional (Neves, 2005). Na educação, o projeto da classe que detém o poder é alinhar as escolas aos padrões e exigências da reestruturação produtiva. Assim, paulatinamente tem buscado revitalizar os princípios da teoria do capital humano, 
acrescentando a ela o entendimento da educação "como componente das fórmulas de aumento da produtividade e de competitividade das empresas no cenário internacional atual” (Freitas, 2014, p. 1087), ou seja, situando a educação como motriz do processo de produtividade e competitividade.

$\mathrm{Na}$ educação brasileira, essa pedagogia da hegemonia vem-se valendo de inúmeras estratégias para a intensificação da lógica capitalista: o ajuste das políticas educacionais às diretrizes com condições adversas ao trabalho e à formação docente; precarização das condições de exercício da profissão; desprofissionalização; perda da autonomia; aligeiramento da formação e intensificação do trabalho; avaliação do ensino com ênfase nas expectativas de aprendizagem e formação em serviço; adesão à pedagogia das competências, entre outras (Freitas, 2002; Fidalgo \& Fidalgo, 2009).

O que está em foco nessa pedagogia da hegemonia é a cultura do desempenho nas práticas educativas a partir de uma lógica utilitarista, que dá ênfase a conceitos como eficiência e eficácia, lógica que vem sendo concretizada à medida que o trabalho docente passa a ser cada vez mais alinhado à razão produtivista (Fidalgo \& Fidalgo, 2009).
Vinculado a essa lógica, o atual Conselho Nacional de Educação - CNE vem propondo e aprovando uma série de documentos que impactam negativamente as políticas de educação e o trabalho docente, compondo um pacote comprometido com a destruição da escola pública e sua privatização (Freitas, 2020).

Tal pacote engloba a articulação entre conceitos presentes na Base Nacional Comum Curricular - BNCC com a adoção da pedagogia das competências que esvazia o caráter crítico, científico e contextualizado da ação educativa, sendo essa pedagogia retomada com força nas Diretrizes Curriculares Nacionais para a Formação Inicial de Professores para a Educação Básica (Resolução MEC/CNE/CP n. 2, 2019) e a Base Nacional Comum para a Formação Inicial de Professores da Educação Básica BNC-Formação.

Os princípios que norteiam esses documentos significam mais um imenso retrocesso para as políticas de formação docente, não só por retirarem a formação continuada do âmbito dos direitos dos educadores, que é obrigação do Estado, mas também por separarem a formação inicial e continuada, e por fomentarem a cultura de responsabilização. Essa postura de culpabilização e responsabilização é resultante dos princípios que orientam a 
Nova Gestão Pública (NGP) que incide sobre as avaliações, principalmente pela articulação do SAEB - Sistema Nacional de Avaliação da Educação Básica com as bases nacionais, a influência de ONGs e Fundações nas políticas educacionais, a adesão a vouchers educativos, que direcionam o dinheiro público das escolas para a iniciativa privada, entre outras ações articuladas (Freitas, 2020; Lima \& Souza, 2020; Curado Silva, 2020).

Importantes estudos (Bazzo, \& Chaibe, 2019; Curado Silva, 2020) vêm alertando sobre os desmontes e retrocessos que a adesão à pedagogia das competências tem trazido para o âmbito das políticas de formação de professores que, por sua vez, deslegitimam projetos com intencionalidades críticas e emancipatórias para a formação docente e desarticulam políticas direcionadas aos sujeitos do campo, indígenas e quilombolas (Silva, et al., 2020).

Integrando o pacote de retrocessos a serviço do capital, no corrente ano o Conselho Nacional de Educação apresenta uma Matriz Nacional Comum de Competências do Diretor Escolar MNCCDE (Minuta de Projeto de Resolução MEC/CNE, 2021) para consulta pública. Tal proposta assume os pressupostos de uma concepção gerencialista e meritocrática de controle e avaliação do trabalho do diretor, caminhando em direção oposta à Constituição Federal de 1988, artigo 206, inciso VII, que estabelece como um dos princípios da educação a "gestão democrática da escola". Convém ressaltar que a polissemia em torno desse conceito será abordada ao se analisar as concepções presentes na referida Matriz de Competências dos Diretores proposta pelo CNE.

A Associação Nacional pela Formação dos Profissionais da Educação ANFOPE e a Associação Nacional de Política e Administração da Educação ANPAE sustentam sólidos argumentos que caracterizam essa Matriz como uma verdadeira afronta à Educação Pública, entre os quais cabe destacar: atribuição à centralidade da figura do diretor na administração escolar; parametrização das funções do diretor; pernicioso alinhamento às diretrizes da Organização para a Cooperação e Desenvolvimento Econômico - OCDE. A respeito dessa organização, Pereira (2016, p. 6) ressalta que a

... OCDE busca subsumir a educação às demandas que emergem do processo de reestruturação do sistema sociometabólico do capital. Sob a ótica neoliberal e da nova gestão pública, sucessivos governos brasileiros aprofundaram as relações com a OCDE, participando de variados espaços da organização e 
subscrevendo protocolos ... que respondem às proposições daquela organização; governo nacional, OCDE e setores empresariais compõem uma tríplice governança e defendem políticas de gestão educacional sob a lógica do desempenho e da política de competências e habilidades, em detrimento do princípio constitucional da gestão democrática.

Esse alinhamento, que está a serviço dos interesses e necessidades da reprodução ampliada do capital, ignora as singularidades do processo educacional no Brasil e das lutas históricas pelo direito à educação no país. Integrada a esses interesses, a MNCCDE (2021) dissemina um equivocado entendimento propalado há tempos pelas classes dominantes, segundo o qual os problemas da educação podem ser resolvidos apenas a partir de "uma gestão eficaz das mesmas formas de organização pedagógica, associada a novas tecnologias educativas, responsabilização, meritocracia e privatização, motivando o neotecnicismo educacional" (Freitas, 2014, p. 1088).

Entre outros graves retrocessos que tal Matriz representa para as lutas históricas pela democratização da educação no Brasil, conforme denúncia feita pela ANFOPE, estão a separação entre as funções de diretor do conjunto de trabalhadores da escola; a definição de competências distantes da realidade brasileira; a visão pragmática que responsabiliza individualmente o diretor pela qualificação das organizações educacionais; a alienação do trabalhador/diretor em relação ao exercício do seu trabalho, entre outros fatores (ANFOPE, 2021).

$\mathrm{Na}$ contramão dessa proposta neoliberal, que pensa a educação somente como mais um nicho de acumulação que pode suprir parte das necessidades da crise estrutural do capital, está a perspectiva de formação de educadores proposta pelas Licenciaturas em Educação do Campo, concebidas com o protagonismo dos movimentos sociais e que compreendem a indissociabilidade das lutas pela terra, trabalho, educação, cultura e território como condição de continuidade de sua existência como campesinato. O projeto formativo de tais Licenciaturas

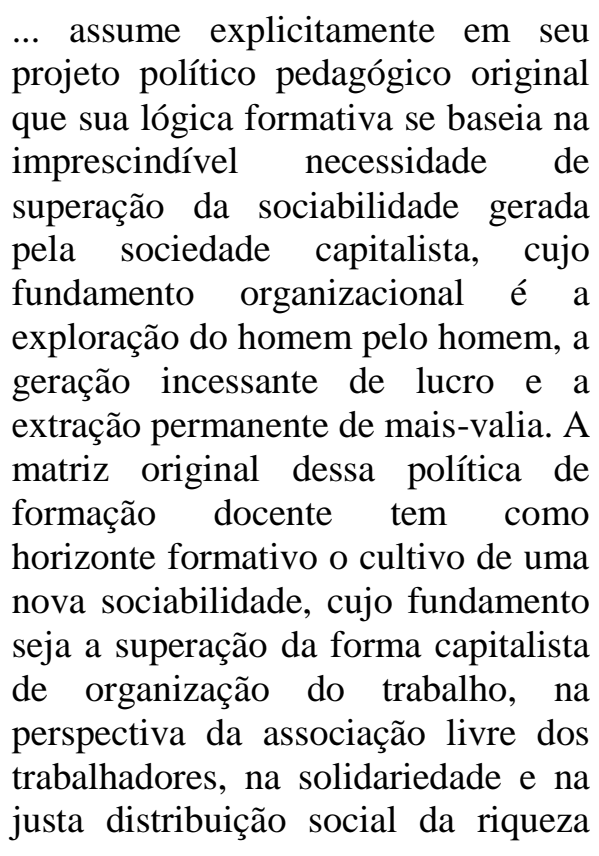
... assume explicitamente em seu projeto político pedagógico original que sua lógica formativa se baseia na imprescindível necessidade de gerada pela sociedade capitalista, cujo fundamento organizacional é a exploração do homem pelo homem, a geração incessante de lucro e a extração permanente de mais-valia. A matriz original dessa política de formação docente tem como horizonte formativo o cultivo de uma nova sociabilidade, cujo fundamento seja a superação da forma capitalista de organização do trabalho, na livre dos justa distribuição social da riqueza 
gerada coletivamente pelos homens (Molina, 2017, p. 592).

As Licenciaturas em Educação do Campo em funcionamento nas cinco regiões brasileiras, presentes em 33 instituições, com 44 cursos permanentes (Molina, 2020), ratificam a defesa de um projeto de educação pública e a formação docente crítica e emancipatória vinculadas à construção de um projeto camponês de desenvolvimento baseado na agroecologia e na soberania alimentar (Tardin \& Ghur, 2017).

Tal como defendido historicamente pela ANFOPE, essas Licenciaturas também têm a compreensão de que a formação do gestor escolar deve-se dar como parte intrínseca da formação de todos os educadores, devendo integrar as habilidades a serem desenvolvidas por eles nos processos de formação inicial.

Nos limites deste artigo, pretende-se desenvolver uma análise mais detalhada acerca da gestão de processos educativos escolares de caráter crítico e emancipador, no sentido de demarcar um espaço de resistência à proposta de uma matriz de competências para o trabalho do gestor escolar, que pode ser protagonizado a partir da proposta de formação docente materializada nos cursos de Licenciatura em Educação do Campo.
Objetivando construir uma reflexão que demonstre na prática a diferença entre essas matrizes formativas, a tessitura deste artigo se organiza em três partes. A primeira traz um aporte sobre as bases político-pedagógicas do neotecnicismo e seus influxos na educação. $\mathrm{Na}$ segunda parte, discute-se sobre os riscos e retrocessos que a MNCCDE (2021) impõe à educação pública de maneira geral. $\mathrm{Na}$ terceira parte, são apresentados os principais elementos da proposta formativa da LEdoC da UnB, trazidos à reflexão com base nos resultados da atuação de seus egressos e egressas que assumiram a gestão escolar de Escolas do Campo (Molina \& Sá, 2012), objetivando identificar os elementos do Projeto Político do curso que podem representar importante resistência àquela proposta de gestão contida na Matriz Nacional Comum de Competências do Diretor Escolar, doravante identificada neste artigo como MNCCDE.

\section{As bases político-pedagógicas do neotecnicismo e seus impactos na educação}

Conforme discutido anteriormente, Luiz Carlos de Freitas (2014) aponta que a lógica empresarial vem norteando as políticas públicas brasileiras com um modelo de escolas produtivistas que ignora por completo a construção coletiva e 
histórica de educadores que resultou nas Conferências Nacionais da Educação CONAEs.

Os reformadores empresariais da educação (L. C. Freitas, 2014) concebemna com base nos moldes gerencialistas de competências, eficiência e eficácia, que têm disputado a orientação das políticas educacionais no Brasil há tempos. Já desde o final da década de 1980, o Consenso de Washington evidenciava a reclamação de organismos internacionais em relação à direção das reformas do Estado nos campos fiscal, trabalhista, administrativo e previdenciário que propõem rigorosos cortes nos gastos públicos. Tais setores buscam implementar contrarreformas orientadas pela lógica do mercado, com fortes influências de organismos multilaterais, tais como a OCDE, citada anteriormente, e o Banco Mundial - BM e o Fundo Monetário Internacional - FMI (Lima \& Sena, 2020).

Esses reformadores da educação no Brasil defendem a tese liberal de que o desempenho dos estudantes brasileiros depende dos méritos de cada um e que, portanto, os resultados das avaliações padronizadas servem para reforçar o funcionamento dos bons resultados para alguns, a partir do acesso à educação superior, e para outros, a inclusão no mercado de trabalho com uma educação tecnicista que visa manter o sistema de exclusão (Freitas, 2012).

A hegemonia da concepção empresarial tem avançado para as múltiplas dimensões que envolvem o processo educacional. Além da disputa pelos fundos públicos que deveriam garantir o direito à educação e pela influência nas políticas educacionais, esse grupo tem-se valido de estratégias bem articuladas: fortalece o impacto das avaliações externas (nacionais e internacionais); padroniza o conteúdo e os objetivos escolares; reorienta diretrizes para a formação de professores; influencia os princípios que regem a escolha de materiais didáticos, entre outras ações que cercam toda a política educacional na direção de redefinir a função da escola e a educação, retirando dela seu caráter público (Freitas, 2014; Shiroma, Garcia \& Campos, 2011).

L. C. Freitas (2016, p. 126) salienta o que está em jogo: "é o controle da escola pública e de seu projeto educativo" com vistas unicamente ao ajuste às expectativas da ordem mundial globalizada, a fim de permitir maior circulação de capitais e de ampliar ainda mais as estratégias de exploração do trabalho pelo capital. O autor reforça que a estratégia dos contrarreformadores é justamente manter o processo de exclusão no qual a classe 
trabalhadora pode avançar nos níveis de escolaridade, porém mantém-se excluída. Para isso, seria necessário padronizar, controlar, supervisionar o acesso ao conhecimento, mantendo-se também o controle político e ideológico da escola. Esse fenômeno há tempos é caracterizado por Luiz Carlos de Freitas como "exclusão por dentro" (Freitas, 2016).

As bases econômicas do neoliberalismo que ancoram essa pedagogia da exclusão remetem à ideia de que a ordem econômica atual não comporta a inserção de todos no mundo do trabalho. Esse é o reflexo do monopólio da ciência e da tecnologia pela automação do processo produtivo que, visando à maximização dos lucros, prescinde de "milhões de braços e cérebros, e amplia a exploração e precarização dos trabalhadores empregados" (Frigotto, 2016, p. 59). Desse modo, alta performance, competitividade, cursos voltados para a empregabilidade e meritocracia são fundamentais para que se perpetue o aumento dos lucros, a extração da mais-valia e a máxima exploração do trabalho humano.

Estudos críticos como o de Helena Freitas (1999; 2002; 2003; 2004; 2007; 2017) vêm discutindo as tentativas de ajuste da formação dos educadores às exigências do trabalho produtivo, estratégia própria do capitalismo. Nos últimos anos, têm sido intensificadas no Brasil a discussão e a inserção de matrizes de competência que devem ser alcançadas tanto pelos professores quanto pelos alunos. São capacidades e competências que têm uma perspectiva unilateral do indivíduo, ou seja, ênfase apenas em aspectos cognitivos de formação, "limitando as enormes possibilidades de formação de nossa infância e nossa juventude para seu desenvolvimento pleno e a produção de uma nova vida" (Freitas, 2003, p. 1116).

A definição de competências centradas nos conhecimentos científicos coloca em evidência apenas uma dimensão da formação do indivíduo e desconsidera uma formação omnilateral que compreenda o sujeito como pleno e integral na perspectiva das múltiplas dimensões do desenvolvimento humano: cognitiva, ética, política, científica, corporal, cultural.

A pedagogia das competências tem forte base construtivista (Sena, 2019), desdobrando-se do entendimento do professor reflexivo (Curado Silva, 2020). Essa pedagogia foi utilizada na década de 1960 pela teoria behaviorista e posteriormente adaptada e associada ao neoconstrutivismo e neopragmatismo, passando a ser entendida como forma de adaptação ao meio material e natural, para 
os quais as competências cognitivas e socioemocionais são necessárias.

Chauí (2014) traz importantes contribuições à discussão sobre as competências, consistindo num poderoso instrumento para perpetuar as relações de dominação. Por esse motivo, as competências são, além de uma ideologia, um mito, pois escamoteiam a real estratégia de se criar "incompetentes sociais" (Chauí, 2014) e ratificam a intencionalidade de exploração econômica, subordinação, controle, punição, dominação política e exclusão social e cultural. Para a autora, "esse mito transforma a capacidade real do processo de conhecimento em álibi para mandar e desmandar. O mito da competência é incompatível com a democracia social, política, econômica e cultural” (p. 102).

A pesquisadora entende que tal ideologia reforça a divisão social na qual, de um lado, estão os competentes, aqueles que dirigem e, do outro, os incompetentes, os que executam de maneira subordinada as ordens. Está posta a dualidade da divisão econômica, política, social e cultural presente nessa perspectiva, em que o sujeito deixa de ser visto em seu contexto histórico e coletivo, e segundo a qual tudo depende do seu esforço individual, abstrato e apartado das relações sociais que o envolvem.
A base pedagógico-administrativa da pedagogia das competências está nos ideais do neotecnicismo, com suas premissas de qualidade total e pedagogia corporativa (Freitas, 2011). Além do problema das competências, é imprescindível também destacar que o viés gerencialista materializa os princípios de submissão do trabalho à lógica do capital. O gerencialismo, assim como a pedagogia das competências, já tem sido uma medida adotada em outros países há pelo menos vinte anos. É por essa via que os serviços públicos são alinhados à perspectiva e exigências do capital, pois é a maneira como os reformadores inserem, no setor público, uma nova cultura organizacional, que é empresarial e competitiva (Ball, 2005). Nas palavras de Beltrão e Tafarell (2017, p. 598), “o capital tem uma agenda para a educação, que, nesse momento, tem centralidade na privatização dos sistemas públicos de ensino".

De forma genérica, é possível elencar alguns elementos que caracterizam essa tendência gerencialista para a educação: substituição do parâmetro éticoprofissional pela competição; transferência de responsabilidades para o profissional, individualmente responsabilizado por sua capacidade de ser ou não eficiente; adoção emergencial de medidas eficazes para a resolução dos problemas enfrentados no 
cotidiano; relações sociais baseadas na competição, na eficiência, na produtividade e no cumprimento de metas; cultura da performatividade, que se refere à comparação entre desempenhos; prevalência da eficácia sobre a ética, provocando individualização e destruindo solidariedades (Ball, 2005).

É essa a lógica neotecnicista que orienta a Matriz Nacional Comum de Competências do Diretor Escolar (2021), proposta que traz sérios riscos e retrocessos à gestão democrática de viés crítico emancipador, ao trabalho do diretor escolar, ao magistério e à comunidade escolar em geral, tal como será mais detalhado na próxima seção.

\section{A Matriz Nacional Comum de Competências do Diretor Escolar: retrocessos e riscos ao princípio da gestão democrática}

$\mathrm{Na}$ seção anterior, argumentou-se que a base política, pedagógica e administrativa da pedagogia das competências está no neotecnicismo (Freitas, 2011), com suas premissas de qualidade total e pedagogia corporativa sob os ditames dos reformadores empresariais da educação. Curado Silva (2020, p. 109) esclarece que a concepção de formação docente da pedagogia das competências

... faz referência a uma perspectiva ideológica de formação e trabalho docente que tem como centralidade somente o conhecimento do conteúdo a ser ensinado como essencial para a construção de práticas docentes que conduzam os alunos à aprendizagem, bem como, à defesa de que o professor deva conhecer aquilo que ensina e como ensina, buscando inovar diante dos problemas da realidade escolar.

$\mathrm{Na}$ introdução deste texto, contextualizou-se a proposta do Conselho Nacional de Educação em estabelecer uma Matriz Nacional Comum de Competências do Diretor Escolar (2021) e construiu-se o argumento de que tal sugestão ratifica uma perspectiva neoliberal, gerencialista, privatista de controle e cerceamento do trabalho do diretor.

Nesta seção, pretende-se continuar a problematização do viés neoliberal dessa proposta, caracterizada pelo gerencialismo na educação; parametrização das funções do diretor escolar; separação desse profissional do coletivo escolar por meio da centralização e de sua responsabilização; seleção e recrutamento desse profissional, incluindo indicações, avaliação, controle, certificação, foco na eficiência e eficácia; intensificação e precarização do trabalho do diretor escolar.

Na continuidade deste debate, serão abordados os riscos e retrocessos que a efetiva implantação da MNCCDE (2021) pode impor à gestão democrática de viés emancipador. Porém, é necessário que 
antes da crítica aos elementos dessa Matriz explicite-se a compreensão que se tem do conceito de Gestão Democrática, que é carregado de grande polissemia.

A gestão escolar brasileira vem sendo discutida ao longo dos últimos trinta e três anos, desde o processo de redemocratização do país, com a superação do regime militar, quando surge o anseio de se consolidar relações mais democráticas. Dal Ri e Vieitez (2010) afirmam que o movimento democrático no Brasil representou uma força ativa fundamental para a emergência da discussão da gestão democrática. Essa força influenciou a Constituição Federal (Constituição da República, 1988), que assumiu princípios nessa direção, incorporando em seu art. 206, inciso VII, o princípio que expressa a garantia da gestão democrática do ensino público.

Tal princípio foi explicitado posteriormente na Lei n. 9.394 (1996), artigos $3^{\circ}$, inciso VIII, e 14, estabelecendo a participação dos diferentes segmentos que integram a vida escolar nas decisões do conselho escolar e garantindo a autonomia em relação à prática pedagógica e à elaboração do Projeto Político Pedagógico.

A gestão democrática é uma prerrogativa legal e vem sendo fortemente ameaçada pelas práticas dos dirigentes públicos que, a partir do contexto político em que estão inseridos, ora tendem a ser autoritários (Dal Ri \& Vieitez, 2010) e nomeiam gestores a partir da relação político-partidária, reproduzindo o sistema de interesses e conveniências a partir de seus interesses eleitorais, ora se deixam cooptar pela lógica empresarial que vem tomando conta dos sistemas educativos no Brasil, com larga incidência nas instâncias definidoras e executoras das políticas públicas.

Para alguns pesquisadores (Sidou, Jimenez \& Gomes, 2014), o debate sobre a gestão democrática comporta a dicotomia entre o compromisso com a cidadania (emancipação política) e o projeto segundo o qual a educação possa cumprir sua função social e vocação de emancipação do humano - condição essencial para uma sociedade efetivamente democrática. Nessa direção, Martins (2012) reconhece que há distintas visões do termo, muitas delas antagônicas entre si, constituindo-o como de natureza plurissignificativa.

Ao afirmar o caráter polissêmico do termo, Martins (2012) ressalta que a gestão democrática tanto pode aparecer no escopo dos princípios gerencialistas, podendo ser cooptado por um paradigma muito distante de intencionalidade maior de seu surgimento no país, quanto ser disputada contra-hegemonicamente, colocando-se ao 
lado das finalidades mais críticas e emancipatórias. Para o autor, por um lado, a flexibilização do conceito administração (tomado aqui como gestão, tanto para o caso educacional quanto de modo geral) pode reforçar o caráter polissêmico do termo gestão democrática da escola; em outro sentido, é justamente essa conceituação que alicerçará os apontamentos acerca da especificidade da gestão democrática nas Escolas do Campo, a ser abordada mais à frente ao se tratar da atuação dos(as) egressos(as) na LEdoC UnB nessa gestão.

Compreende-se aqui a gestão democrática na perspectiva das disputas contra-hegemônicas que não renunciam ao horizonte da emancipação humana, não se contentando somente com a emancipação política ou com a perspectiva de alienação do trabalho. Ainda considerando a polissemia do conceito, Molina (2012, p. 588-589) argumenta:

É em torno da ideia da igualdade jurídico-política que se processam as críticas dos opositores à importância adquirida pelas lutas por políticas públicas. A pertinente crítica que se faz é que a igualdade jurídico-política oculta a impossibilidade de a igualdade real se materializar nas sociedades capitalistas: existe nelas uma barreira intransponível para a igualdade real entre os sujeitos decorrente da instituição da propriedade privada, que impede os sujeitos de serem iguais de fato, visto que uns se apropriam privadamente dos meios de produção e da força de trabalho de outros ... Mesmo com esses limites e ressalvas, é ainda extremamente relevante a luta pela garantia da igualdade jurídico política, pois ela significa espaços de resistência dos avanços já conquistados pela humanidade em torno do ideal dos direitos humanos, embora saibamos que nosso horizonte para garantir a liberdade de fato para todos é bem maior.

Em sintonia com as reflexões de Molina, Schlesener (2019, p. 363-365) faz uma síntese clara sobre a complexidade do conceito de gestão democrática:

O problema da gestão não é apenas de diretriz política de governo, da funcionalidade das políticas públicas e sua realização prática, mas de como a gestão expressa um projeto de sociedade e de como reflete as mudanças que ocorrem a partir do modo como os grupos sociais se inserem na vida produtiva da sociedade (Gramsci, 1978, Q. 15, p. 1807). Portanto, falar de gestão democrática pressupõe dizer de qual gestão e de qual democracia se fala, visto que a grande política compreende a natureza do Estado e sua tarefa, na sociedade burguesa, de defender e conservar determinadas estruturas econômicas e sociais. Se não se explicita a posição política da qual se parte, se fala sempre em abstrato mistificando a realidade, visto que falar em abstrato significa apoiar-se em uma forma sem conteúdo.

...

Essas questões remetem-nos a outras, como as que se apresentam no Caderno 15, sobre a formação dos dirigentes, na qual há uma premissa fundamental que é: se quer que existam sempre dirigentes e dirigidos ou se deseja criar s condições a partir das quais essa divisão desapareça? Nas relações políticas, tem-se como 
pressuposto a eterna divisão do gênero humano ou se acredita que essa divisão é um fato histórico e, portanto, pode desaparecer? Toda a filosofia e a arte política devem partir dessas premissas e a sua base é a divisão social do trabalho (Gramsci, 1978, Q. 15, p. 1752). Aqui Gramsci esclarece que a origem das divisões políticas se encontra na estrutura econômica da sociedade. Esquecer esse pressuposto implica apresentar uma definição abstrata de democracia e, consequentemente, de gestão democrática. A abstração caracterizase por uma forma sem conteúdo, ou seja, um discurso vazio.

Portanto, neste artigo corroboram-se as críticas endereçadas à MNCCDE (2021), que são várias e muito contundentes. Tais críticas reúnem posicionamentos de importantes segmentos da sociedade brasileira no âmbito educacional, vindas de diferentes áreas do conhecimento, tais como: a Associação Brasileira de Alfabetização - ABAlf; Associação Brasileira de Pesquisa em Educação em Ciências; Associação Brasileira de Currículo - ABdC; Associação Nacional de Pesquisadores em Financiamento da Educação FINEDUCA; Associação Nacional de PósGraduação e Pesquisa em Educação ANPEd; Associação Nacional pela Formação dos Profissionais da Educação ANFOPE; Centro de Estudos, Educação e Sociedade - CEDES; Confederação Nacional dos Trabalhadores em Educação - CNTE; Fórum Nacional de
Coordenadores Institucionais do Pibid e Residência Pedagógica - ForPibid-RP; Fórum Nacional de Diretores de Faculdades, Centros de Educação ou Equivalentes das Universidades Públicas Brasileiras - ForumDir; Sociedade Brasileira de Educação Matemática SBEM; Sociedade Brasileira do Ensino de Química - SBEnQ, etc.

A proposta da MNCCDE (Minuta de Projeto de Resolução MEC/CNE, 2021) camufla, através da apropriação de categorias pertencentes a outro paradigma educacional (pluralismo, valorização profissional, trabalho coletivo, participação, entre outras), as verdadeiras intencionalidades fundamentadas de fato em princípios alinhados à perspectiva neoliberal, que conduz as políticas educacionais sob um viés gerencialista muito comprometido com bases demarcadas internacionalmente.

$\mathrm{O}$ arquétipo de diretor projetado pelo viés gerencialista, conforme Gewirtz e Ball (2011) ressaltam, valoriza a capacidade tácita e sem questionamentos de um gestor com esse perfil a implementar de maneira consentida e com eficiência objetivos e princípios que são projetados fora da escola. Esse perfil de diretor estaria "frequentemente articulado a um vocabulário da empresa, excelência, qualidade e eficiência” (p. 199). 
O objetivo da referida Matriz é "parametrizar os diversos aspectos concernentes à função do Diretor Escolar, auxiliando na definição de políticas nacionais, estaduais e municipais direcionadas para sua formação inicial e continuada" (Minuta de Projeto de Resolução MEC/CNE, 2021, p. 3). Obviamente, para criar parâmetros de competência do gestor escolar, parte-se da análise de eficiência e eficácia pautada nos resultados das avaliações padronizadas, tendo como base estudos e referências teóricas americanas, que nada têm a ver com a realidade dos territórios brasileiros, ainda mais se consideradas as várias especificidades das escolas localizadas nos territórios camponeses no país. Essa parametrização é, sem dúvida, um aspecto extremamente perigoso da referida Matriz.

A ANPAE já se posicionou sobre o quanto essa orientação fere as distintas realidades materiais e físicas das escolas, ao afirmar que

... utilizar parâmetros para formação e atuação do profissional da educação alinhados à lógica neoliberal, se contrapõe à defesa da educação cidadã como direito, os quais tendem a impactar a gestão das instituições educativas, seus processos de participação e decisão coletiva, bem como, a formação e atuação dos/as professores/as, ao dicotomizar o pensar e o fazer político-pedagógico e naturalizar a distinção entre o/a diretor/a e os demais profissionais da educação, bem como, ao reduzir a atuação deste profissional a competências e habilidades genéricas e descontextualizadas (ANPAE, 2020, p. 3).

No âmbito da Educação do Campo, esse entendimento fere também o que está posto nas próprias Diretrizes Operacionais para a Educação Básica nas Escolas do Campo (Parecer MEC/CNE/CEB n. 36, 2001), que orientam as Escolas do Campo e sua gestão a buscarem uma intrínseca vinculação com as questões inerentes à vida social, cultural e política das comunidades rurais nas quais se inserem. De acordo com tal marco legal, conquistado pela luta coletiva dos sujeitos do campo, o que deve orientar a atuação da gestão de tais unidades escolares são os desafios impostos à reprodução material da vida dos sujeitos camponeses que as frequentam, considerando, inclusive, as tensões e contradições em torno dos projetos de campo no país entre a Agricultura Familiar Camponesa e o Agronegócio, e os desafios que tal disputa impõe a essas escolas, o que será objeto de maior detalhamento no próximo tópico.

Além disso, a MNCCDE (2021) separa o diretor do coletivo escolar e atribui a ele uma centralidade que fere profundamente o princípio da gestão democrática. Essa Matriz concebe o papel do diretor como determinante na garantia de uma escola pública de qualidade para 
todos e chega a considerar que o "diretor é o responsável geral pela escola, garantindo as condições de funcionamento adequado à sua função social" (Minuta de Projeto de Resolução MEC/CNE, 2021).

A crítica a essa abordagem recai sobre o fato de essa enorme centralidade da figura do Diretor colocar a gestão democrática em segundo plano e desconsiderar a realidade local, que é histórica, social, cultural e política. Além de dar centralidade à figura do diretor, a Matriz o responsabiliza pelas questões educacionais, que são muito mais amplas e complexas. A ANPAE (2020) critica essa visão, por prescindir de todos os outros participantes do espaço educativo que deveriam também coprotagonizar os processos formativos que ocorrem na escola.

Há sérios riscos quando se aparta o gestor escolar do coletivo de profissionais que integram a escola. A condução dessa proposta esvazia enfaticamente as referências estabelecidas pela Resolução MEC/CNE/CP n. 2 (2015), que sustentam o entendimento de que o diretor integra os profissionais do magistério da Educação Básica. Além disso, a questão da gestão democrática é amplamente defendida e referendada nas Diretrizes Operacionais para a Educação Básica nas Escolas do
Campo (Parecer MEC/CNE/CEB n. 36, 2001), dispondo que o

... projeto institucional das escolas do campo, consideram o artigo $14 \mathrm{da}$ LDB que garante a gestão democrática, constituindo mecanismos que possibilitem estabelecer relações entre a escola, a comunidade local, os movimentos sociais, os órgãos normativos do sistema de ensino e os demais setores da sociedade.

Um aspecto de extrema gravidade da referida Matriz proposta pelo CNE é a possibilidade de indicação de diretores por critérios de seleção e recrutamento. Há várias referências no texto da Matriz ao Relatório "Ativando dispositivos políticos para Educação 2030" (Unesco, 2018), que defende a criação de uma agenda de políticas públicas educacionais na qual conste que a possibilidade de indicação do diretor é não somente possível, mas também recomendável. Ao estabelecer critérios para a seleção e recrutamento dos diretores, uma prática autoritária, subentende-se que a eleição democrática protagonizada pelos diferentes segmentos da comunidade escolar é negligenciada, favorecendo indicações com base em critérios subjetivos, políticos e não democráticos (Martins, 2012).

Outro ponto questionável da MNCCDE (Minuta de Projeto de Resolução MEC/CNE, 2021) é que não apenas atribui competências ao diretor, 
mas se propõe à avaliação do cumprimento das metas que ele deve atingir, ou seja, além de ser uma gestão por competências, há também o entendimento de que tais competências devem ser avaliadas, supervisionadas e controladas por outros sujeitos de fora da comunidade escolar.

Entre os problemas dessa intencionalidade de responsabilização, o documento não deixa explícito se essa deverá ser uma incumbência da esfera pública ou se a iniciativa privada é que fará esse controle, ratificando a influência do setor privado na educação pública. Inferese, a partir de uma análise do conjunto dessa proposta, que se trata de uma responsabilização participativa. Conforme a análise de Freitas e Sordi (2013), trata-se de uma contrarregulação em que múltiplos atores que se dizem interessados na qualidade educacional interferem nesse contexto para alinhá-lo aos princípios e ditames da lógica do capital e dos interesses dos setores econômicos. Tais atores passam a "deliberar sobre os objetivos e compromissos inerentes às concepções mais amplas de qualidade educacional" (p. 91).

A concepção empresarial de gestão que impregna essa Matriz é também perniciosa em mais um aspecto: o foco na eficiência e eficácia no sentido de "garantir que os recursos e trabalhadores da escola sejam organizados e dirigidos de forma eficiente, adequada e com qualidade para fornecer um ambiente de aprendizagem eficaz e de desenvolvimento seguro" (Minuta de Projeto de Resolução MEC/CNE, 2021, p. 5). A ANPAE destaca que esse entendimento transpõe para a escola pública a visão do mundo corporativo das empresas, impregnando-a com uma lógica pragmática, competitiva e meritocrática, afastando-se profundamente das reais funções sociais da escola e da educação.

Merece também atenção e crítica a perspectiva de responsabilização e intensificação do trabalho do gestor, que passa a ser responsável pela integridade física, moral e psicológica das pessoas que trabalham na escola. Soma-se a isso a sua prerrogativa de aplicar sanções disciplinares regimentais a professores, servidores e estudantes. O equívoco de tal Matriz chega ao ponto de estabelecer que compete ao gestor garantir resultados na melhoria da aprendizagem no prazo de dois a sete meses do mesmo ano, tese completamente insustentável. Deixar a cargo somente do diretor e do vice-diretor essas ações é centralizar a gestão e retornar a educação aos processos autoritários que vão de encontro à Lei de Diretrizes e Bases da Educação Nacional, artigos 12, 13 e 14 (Lei n. 9.394, 1996, art. 14), que, além de 
prever competências de gestão, garante a participação de toda a comunidade escolar. Nesse sentido, é importante dar especial ênfase ao art. 14 da mesma lei, que prevê o princípio da participação de todos os profissionais da educação na elaboração do Projeto Político Pedagógico e da comunidade escolar em instâncias colegiadas de participação.

Ravitch (2011, p. 254) sustenta o argumento de que não é critério de melhoria da escola esse controle excessivo exercido pelo diretor. Para a autora, o diretor não deveria ser esse "professor chefe da escola", que centraliza em si a tarefa de controlar, supervisionar e avaliar a equipe.

Nessa concepção, seria considerável o potencial de alienação que a função do diretor passaria a ter. Isso é próprio do neotecnicismo, que negligencia a concepção ampla de gestão defendida pela ANPAE:

Essa afirmação, constante do documento em pauta, além de revelar uma visão tecnicista e pragmática da gestão escolar, traz a intenção de que os padrões arrolados venham a servir para controle, regulação e avaliação dos/das profissionais, neste caso o/a diretor/a, o que tende a se traduzir na intensificação da lógica concorrencial e culpabilização individual dos/das profissionais da educação pelos resultados educacionais, vindo a apoiar iniciativas de premiação e punição (ANPAE, 2020).
Destaca-se aqui a concordância com as conclusões de Ravitch (2011, p. 251) em relação ao entendimento de que os problemas da educação brasileira não se resolvem na reestruturação da forma de administração, não se trata de "um problema administrativo que requer o alistamento de um exército de consultores empresariais". Tanto na análise de Ravitch (2011) quanto na de L. C. Freitas (2020), países como Estados Unidos, onde essas práticas estão em curso há mais tempo, foram constatados retrocessos e piora na qualidade educacional, ou seja, os parâmetros empresariais de eficiência, eficácia, competitividade e parametrização só servem para esvaziar a escola de sua função social.

Em síntese, além de ferir mortalmente o princípio da gestão democrática, a Matriz ataca também os gestores escolares da Educação do Campo, uma vez que ter um parâmetro único de competência retira a possibilidade de singularidade da relação com os territórios. Compreende-se ser urgente e necessária uma contraposição a tal marco legal, pelos enormes retrocessos que apresenta. Considera-se também necessário destacar a compreensão que se tem sobre a real possibilidade do constructo histórico da Educação do Campo e da proposta de formação docente que ela constrói a partir 
da Licenciatura em Educação do Campo de contribuir com significativos elementos para subsidiar parte das lutas de resistência a esse nefasto projeto de destruição e privatização da educação pública.

\section{A práxis dos(as) egressos(as) na gestão das Escolas do Campo: identificando contribuições do Projeto Político Pedagógico da LEdoC UnB para a resistência à MNCCDE}

$\mathrm{Na}$ contramão dessa proposta neoliberal abordada nas seções anteriores, desde 2007, como desdobramento das lutas e experiências acumuladas na formação de educadores a partir dos cursos do PRONERA (Molina, Santos \& Brito, 2020), os movimentos sociais lograram a criação do Programa de Apoio à Formação Superior em Licenciatura em Educação do Campo - PROCAMPO, voltado especificamente para a formação de educadores e educadoras do campo e para "que se constitua desde a especificidade do campo (que inclui uma estrita relação entre educação e processos de desenvolvimento comunitário)" (Caldart, 2011, p. 99).

Nos limites deste artigo não é possível apresentar um histórico completo do processo de elaboração e implementação do PROCAMPO no Brasil, no entanto várias pesquisas já têm registrado essa construção coletiva e podem ser consultadas com mais precisão e detalhes em outros trabalhos já publicados, como os de Molina e Sá (2011) e Molina e Hage (2015). Já estão publicizados também diversos resultados de pesquisas sobre os principais elementos que dão sustentação ao Projeto Político Pedagógico da própria Licenciatura em Educação do Campo da Universidade de Brasília, tais como: Molina e Sá (2011), Molina (2015, 2017), Nascimento (2019), Ferreira (2015), Brito (2017), Pereira (2019), Silva (2019) e outros.

Os dados gerados e discutidos nesta seção são provenientes da análise documental de Projetos Políticos Pedagógicos dos quais os sujeitos desta pesquisa participaram da elaboração e implementação. Tais dados também são provenientes das pesquisas realizadas por esses sujeitos na formação inicial e continuada, e apresentados por eles em roda de conversa.

Na tessitura textual desta seção, apresentam-se inicialmente os sujeitos colaboradores da pesquisa e o contexto social no qual estão inseridos. $\mathrm{Na}$ sequência, apresentam-se algumas categorias evidenciadas nos dados analisados e que consistem em referências para o enfrentamento da Matriz Nacional de Competência Comum do Diretor Escolar. 
Hoje, nesse recomeço de luta eu Adão Fernandes da Cunha como professor da rede estadual há quase uma década, licenciado pela Educação do Campo/UnB, Mestre em Desenvolvimento Sustentável também pela UnB e pedagogo tenho muita gratidão por ser o escolhido e honra de assumir a Direção das Escolas Kalungas dos municípios de Cavalcante - Goiás, Teresina de Goiás e Monte Alegre de Goiás. E ao assumir faço, saber da minha alegria, carinho, respeito e admiração por todos os companheiros dessa jornada e pelo trabalho que conheço de cada um de vocês ... respeitosamente em nome do povo Kalunga como novo Gestor das escolas quero agradecer profundamente a cada um de vocês a quem esta mensagem está direcionada. Em todos esses anos de lutas para que essa mudança na gestão escolar Kalunga pudesse ser assumida por um gestor das próprias comunidades é um marco que jamais deverá ser esquecido. Quero dizer que em meio a tantas crises econômicas e sociais no momento em que o Brasil e o mundo sofrem com a pandemia do COVID19, eu hoje 22 de abril de 2020, assumo a gestão, mas não sou eu quem vou estar lá na frente e sim nós como um coletivo da massa que luta. Abraços fraternos do novo Diretor das Escolas Kalungas, Adão Fernandes da Cunha (Grifos nossos).

Esse extrato da fala de um egresso da LEdoC UnB, professor Adão Fernandes da Cunha, sujeito colaborador da pesquisa e atual diretor da Escola Estadual Calunga III, localizada em Teresina de Goiás, é analisado quinze anos após a publicação da Minuta original que orienta a criação dos cursos de Licenciatura em Educação do Campo (Molina \& Sá, 2011). Os trechos grifados servem para destacar a significância de um estudante egresso do Curso de Licenciatura em Educação do Campo da Universidade de Brasília assumir a gestão das Escolas do Campo de seu território quilombola.

Adão, egresso da LEdoC UnB, é um gestor da própria comunidade, formado para atuar na docência, na gestão e na organização dos processos escolares e comunitários, conforme o PPP citado anteriormente, com consciência da importância de contribuir com a organização do trabalho escolar e pedagógico a partir dos sujeitos coletivos do campo que representa. Ainda está atuando na gestão da Escola Estadual Calunga III, em Teresina de Goiás, que integra o Território do Quilombo Kalunga, Cavalcante, Goiás, desde maio de 2021.

O território Quilombola Kalunga, considerado o maior quilombo do país, está situado na parte nordeste de Goiás, distribuído nos municípios de Cavalcante, Teresina de Goiás e Monte Alegre, ocupando uma área de 253.000 hectares. Esse povo herda uma história marcada por lutas e resistência por ser uma comunidade descendente de negros que foram escravizados. É um território é gerido por importantes associações comunitárias que representam as comunidades cumprindo uma função legal junto aos órgãos do Estado (Gomide et al., 2019). Em sua Dissertação de Mestrado, Adão Fernandes da Cunha afirma que 'Esse quilombo foi construído historicamente pela luta dos negros contra a escravidão. Os negros 
escravos refugiados foram-se espalhando e procurando os lugares mais secretos a fim de ter direito à vida e construir famílias' (Adão Fernandes da Cunha, 2018, p. 18).

É importante destacar que, no intervalo de abril de 2020 a abril 2021, Adão foi o responsável pela gestão das Escolas do Campo dos três municípios que abrangem o território do Quilombo Kalunga (Cavalcante, Monte Alegre e Teresina), estando nesse período sob sua responsabilidade as Escolas Estaduais Calunga I, II, III, IV e V, e suas extensões, perfazendo um total de dezoito escolas.

A partir das próprias lutas empreendidas junto ao governo do estado pelas associações presentes no território em parceria com o próprio Adão, foram conquistadas vagas para gestores específicos das Escolas do Campo de cada um dos três municípios que integram o Quilombo Kalunga. Adão destaca que

... as nossas escolas não tinham tido a oportunidade de receber nenhum gestor que tivesse essas experiências, que tivesse 0 sangue das Comunidades... E aí para assumir a direção dessa escola não foi por indicação foi por um processo de luta nosso enfrentando o governo estadual, indo em muitas reuniões com a secretária e levamos nossas pautas, as nossas demandas porque a gente estava entendendo ainda que esse processo de formação é humana e a formação na educação ainda hoje ela estava, por mais que nós professores já tivessem sua experiência da Educação do campo, ela estava caminhando para um outro destino ... Então depois de muita luta em 2020, especificamente em abril, eu fui indicado pela comunidade, na reunião presente no gabinete de secretária para assumir a gestão de 18 escolas do território Kalunga, em três municípios diferentes" (Adão Fernandes da Cunha, Entrevista).

Apesar de as escolas estarem localizadas em diferentes territórios, a particularidade de sua criação é um fator que não se pode deixar de destacar, uma vez que é princípio fundante da Educação do Campo a relação entre as lutas pela terra, pelo território e pela educação.

A singularidade da ocupação de espaços na gestão escolar em Escolas do Campo por egressos(as) da LEdoC UnB é o elo comum entre os sujeitos que integram a parte da pesquisa vinculada ao $\mathrm{CNPq}$ socializada neste artigo. Por meio de rodas de conversa, foram entrevistadas também duas egressas dessa Licenciatura que já assumiram a gestão escolar em suas comunidades, sendo ambas eleitas para duas gestões consecutivas: Ângela Cristina Alves (Diretora da Escola Estadual Ernesto Che Guevara - Assentamento Antônio Conselheiro, Tangará da Serra/MT, gestões de 2014 a 2018) e Luzinete Jesus de Oliveira Tolomeu (Diretora na Escola Municipal Paulo Freire - Assentamento Paiol, Cárceres/MT, gestões de 2014 a 2018).

Se para Adão assumir a gestão das escolas Calunga trata-se de um processo de 
inventividade, criatividade e possibilidade de transformação da gestão escolar, considerando que o território em questão é um quilombo historicamente marcado pela resistência e pela organização social de uma população tradicional, no território de Mato Grosso ambas as escolas em foco também foram conquistadas por elas a partir da luta dos trabalhadores, desde o acampamento até a conquista dos assentamentos onde se situam.

A Escola Municipal Paulo Freire nasceu da luta dos trabalhadores e trabalhadoras, adultos, jovens e crianças, sob a organização do MST (Movimento dos Trabalhadores rurais Sem-Terra), de forma coletiva e organizada, travou uma forte batalha de cidadania. Foram construídas cinco escolas de palha, nos diversos setores do acampamento: Corguinho, Chico Mendes, Monjolo, Lagoa e Igrejinha. No de 1997, com o Decreto $n^{\circ} \quad 76 / 98$ foi oficialmente criada a Escola Municipal Paulo Freire, que está localizada na área social central do projeto de Assentamento Nova Conquista. A escola atende a educandos da Educação Infantil e do $1^{\circ}$ ao $9^{\circ}$ ano durante o período matutino e vespertino, filhos de acampados, funcionários de fazendas vizinhas, além dos educandos da própria comunidade e conta com uma sala anexa no assentamento vizinho Limoeiro, aproximadamente $35 \mathrm{~km}$ da sede da escola (Projeto Político Pedagógico Escola Paulo Freire, 3).

A Escola Ernesto Che Guevara localiza-se no Assentamento Antônio Conselheiro que situa-se em 03 (três) municípios (Tangara da Serra, Barra do Brugre e Nova Olímpia); são 37 mil hectares de terra. ... Em 1998, a prefeitura, em resposta à pressão da comunidade, doou uma escola desativada de madeira e apoiou os moradores em sua reconstrução no assentamento (PPP, 2015). No ano de 2005 foi inaugurada a escola reformada, já de alvenaria. A partir desse momento, a retomada do ensino noturno possibilitou a volta dos assentados à escola e o aumento de mais de $50 \%$ no número de estudantes ... Em 2014, foi eleita para a direção Ângela Cristina Alves, egressa da Licenciatura em Educação do Campo/Linguagens da Faculdade UnB - Planaltina. A diretora Ângela ... protagonizou um movimento de articulação da rede de escolas do campo da região e de parcerias com distintas universidades federais brasileiras (Souza \& Brick, 2017, p. 31).

A permanência de egressos(as) em seus territórios de origem e a possibilidade de assumirem a gestão das escolas nesses mesmos espaços são das primeiras dimensões a serem pautadas como repercussões positivas da atual pesquisa, pois remetem à intrínseca relação com o trabalho e com a forma de produção e reprodução material da vida dos sujeitos camponeses e sua relação com a terra, objetivo pelo qual a Educação do Campo vem sendo forjada num projeto que almeja a justiça e a igualdade social. Essa repercussão não pode ser dissociada da importância da oferta dessa Licenciatura a partir da Alternância Pedagógica (Molina, Martins \& Antunes-Rocha, 2021), que de fato tem contribuído significativamente para que os sujeitos camponeses acessem a 
Educação Superior sem perder o vínculo com seus territórios.

Com a intencionalidade de trazer à análise a atuação de egressos(as) da LEdoC UnB que estão atuando ou já atuaram na gestão de processos educativos escolares na região Centro-Oeste, no sentido de demarcar um espaço de resistência à proposta da MNCCDE, serão apresentados nesta seção extratos da pesquisa sobre a práxis de tais egressos(as), que podem trazer pistas significativas indicando elementos importantes de serem mantidos nos projetos que querem contribuir com a formação de educadores críticos e autônomos, formados como sujeitos sóciohistóricos, conforme defendido pela ANFOPE.

Para o objeto específico da reflexão que se quer desenvolver neste texto, os dados gerados e analisados foram organizados considerando seis categorias: a) busca pela intrínseca articulação entre as lutas pelo direito à terra, ao trabalho e à educação - compromisso político; b) unidade Teoria-Prática na perspectiva da práxis; c) trabalho coletivo e participação da comunidade; d) auto-organização e f) democratização da gestão na direção da autogestão.

A primeira categoria emergente nas falas esteve relacionada ao compromisso político, quer dizer, à intrínseca relação entre as lutas pelo direito à terra, trabalho e educação. Com a intencionalidade de captar como os(as) egressos(as) da LEdoC UnB têm firmado seu compromisso político e compreendido sua ação como gestores, teve-se com eles um diálogo sobre suas concepções de educação, formação humana, função social da escola, trabalho coletivo e sobre os aspectos que consideram mais importantes em seu trabalho nos termos da gestão democrática, no sentido de transformação da forma escolar, bem como os maiores desafios enfrentados para promovê-la na direção proposta pela Educação do Campo

A LEdoC traz muito forte e muito bem esses princípios de identidade étnica, quando trabalha os sujeitos de direito. Tanto sujeitos do campo, quanto a identidade negra, como todos os sujeitos que fazem parte de diferentes comunidades. A LEdoC trabalha a identidade dos sujeitos de maneira muito dinâmica, fazendo essa interação das várias interações sociais, das várias culturas que o Brasil tem. [os egressos] saem com a compreensão de que pertencem a outras comunidades porque querendo ou não todos os todos os sujeitos do campo, negros, quilombolas e indígenas têm uma relação histórica que tem uma raiz muito próxima. Então esses sujeitos de direito têm muita coisa em comum e a LEdoC trabalha isso muito bem aproxima esses sujeitos e faz com que essa coletividade vá a cada dia mais ganhando força e reconstruindo as identidades uns de maneira muito colaborativa com os outros sujeitos 
também do Campo (Adão Fernandes da Cunha, dados da pesquisa, 2021). Educação humanizadora é isso, ela tem que fazer você se sentir mais humano. Um processo que indigna, que faz movimentar para além do que está acostumado. Te desafia a todo momento e te faz movimentar (Ângela Cristina Alves, Entrevista).

Assim, é imprescindível destacar a centralidade atribuída pelo PPP da LEdoC UnB à perspectiva de formar educadores que se sintam e se vejam como "lutadores e construtores do futuro" (Pistrak, 2013) e que tenham consciência da indissociabilidade da relação entre educação e política, entre educação e projeto histórico de sociedade (Mészáros, 2008), entre educação, hegemonia e contra-hegemonia, com especial clareza de seu papel na construção das lutas contrahegemônicas (Gramsci, 1991).

A educação tem um papel fundamental no processo de produção e elevação da consciência dos sujeitos camponeses a respeito de sua condição de sujeitos de direitos e de seu papel no âmbito dos deveres e a respeito das tarefas que devem assumir na sociedade para contribuir com sua transformação e mudança. Krupskaya (2017), já em 1915, no clássico texto "As Tarefas Educativas da Escola", alertava sobre a importância de a escola ser capaz de construir, junto à juventude, esse senso de responsabilidade e pertencimento. E tal compreensão de si mesmo como lutador e construtor do futuro se fez presente nas falas de cada um dos três diretores entrevistados.

Destaca-se como questão central do Projeto Político Pedagógico original das Licenciaturas em Educação do Campo sua vinculação às lutas da classe trabalhadora do campo, ligando-se à produção material da vida e produção cultural dos sujeitos do campo, das quais decorre a necessidade de uma clara redefiniç̧ão das funções sociais da escola pelo cultivo de uma nova sociabilidade "na direção da associação livre dos trabalhadores, na solidariedade e na justa distribuição social da riqueza gerada pela coletividade humana" (Molina, 2017).

Entre as especificidades desse Projeto Político Pedagógico das LEdoCs, destacam-se algumas características relevantes que, além de constituírem um perfil específico do educador a ser formado, também têm direta repercussão nos debates sobre o papel que podem vir a desempenhar tais educadores quando assumem a gestão das Escolas do Campo e as potencialidades que podem ter no enfrentamento à MNCCDE. São as seguintes essas características: a) formação para a docência multidisciplinar por áreas do conhecimento; b) perfil profissional projetado para o curso, que envolve 
também a formação para a gestão de processos educativos escolares e a gestão de processos educativos comunitários; c) organização curricular por meio da Alternância Pedagógica; d) perspectiva da formação de um educador com compromisso político que lhe permita a transformação da forma escolar; e) busca da vinculação com a produção material da vida e produção cultural dos sujeitos do campo; f) humanização da docência e busca pela superação da fragmentação do conhecimento; g) fomento de intencionalidades que permitam a ampliação da compreensão da totalidade dos processos sociais pelas mulheres e homens do campo.

Um segundo elemento identificado nos dados analisados foi o entendimento da unidade teoria-prática na perspectiva da práxis. Compreende-se a práxis como uma das categorias centrais da filosofia marxista, uma vez que ocupa lugar de critério de validação da verdade. Tal categoria tem como sua característica estruturante a necessidade de formar sujeitos que, além de compreenderem criticamente o mundo, sejam capazes de promover ações no sentido de transformálo. De acordo com sua etimologia, como afirmamos em trabalho anterior,

... a palavra práxis origina-se do verbo latim pattin remetendo à ideia de ação com um fim em si mesma, na qual o resultado não está dissociado do sujeito que a realiza. Trata-se de uma relação de unicidade entre a teoria e a prática intencionada à compreensão do mundo e suas contradições, a nortear a transformação dele (Noronha, 2010). Esta unidade (teoria-prática) é dinâmica, na medida em que agrega o ato de pensar e fazer em uma mesma ação ... A práxis está, então, articulada com a produção material da vida de transformação recíproca do mundo e do próprio homem. Ao tomarmos a práxis como categoria fundamental e estruturante de uma proposta de transformação da forma escolar, concordamos com Noronha, ao afirmar que é necessária, também, uma visão de sujeito alinhada a essa perspectiva: '... não como um ser passivo, mas como um ser social que age no mundo com o objetivo de transformá-lo de acordo com um fim' (2010, p. 12). Isto significa que se trata de um sujeito reconhecido em sua dimensão concreta e historicamente situada, protagonista diante do movimento do real e, por isto, históricos e sociais, que atuam na realidade material para transformá-la, assumindo a perspectiva de classe dos trabalhadores (Molina \& Pereira, 2019, p. 32).

Especificamente no curso de Licenciatura em Educação do Campo da UnB, a partir da relação com o território de origem - na relação teoria e prática -, há significativo esforço e investimento para que os estudantes desenvolvam suas atividades acadêmicas nos próprios territórios de origem a partir das atividades previstas no curso, via Inserção Orientada na Escola - IOE e Inserção Orientada na Comunidade - IOC. Isso gera vínculo na 
prática da formação de professores para a Educação Básica no campo, visto que a mediação entre o processo de formação do educador e seu lócus de formação é a Escola do Campo.

Inserção Orientada se refere às ações articuladas pela Licenciatura em Educação do Campo que orientam e direcionam a inserção dos estudantes em uma determinada realidade, organização ou em um determinado processo, espaço, território. Há dois tipos de inserção orientada: na escola e na comunidade. A Inserção Orientada na Escola - IOE se refere à estratégia que fomenta a inserção no contexto escolar, por meio da qual se espera a atuação dos sujeitos em formação na Licenciatura e a formação para o trabalho na educação, estando em contato com escolas concretas no território em que vivem. A Inserção Orientada na Comunidade - IOC, agrega a intencionalidade de fortalecimento do vínculo escola e comunidade, ou seja, a aproximação dos processos educativos e a vida. Visa a compreensão crítica e construção de uma visão transformadora da realidade, principalmente do projeto de desenvolvimento que está em curso na comunidade buscando a transformação social. Nessa inserção a comunidade, suas contradições, tensões, desafios e tramas são os objetos de estudo, buscando compreender e atuar em sua relação com a escola (Barbosa, 2012).

Essa concepção de formação do PPP

da LEdoC fundamenta-se na leitura segundo a qual a compreensão do fenômeno educacional exige que se compreenda também seus fundamentos históricos, políticos e sociais, com ênfase na concepção sócio-histórica de leitura do real e nas lutas articuladas com os movimentos sociais (ANFOPE, 2006, p. 16-17).

Essa sólida formação proposta pelo PPP da LEdoC UnB (Molina, \& Hage, 2015, p. 140), funda-se na

... compreensão da necessidade de construir estratégias formativas que sejam capazes de oportunizar ao docente em formação a superação da visão restrita dos limites e potenciais de sua ação, ofertando-lhes, durante o percurso formativo, os fundamentos teóricos necessários para o educador ir localizando os efeitos e resultados de sua ação educativa a partir de um contexto bem mais amplo que a contém. Com a intencionalidade de formar educadores capazes de compreender a totalidade dos processos sociais em que estão inseridos os educandos do campo com os quais docentes em formação irão trabalhar -, a referida Licenciatura tem buscado promover práticas educativas que sejam capazes de criar condições necessárias para a compreensão dos processos sociais de ensinoaprendizagem nessa dimensão. O que tem requerido que, nessa graduação, se façam presentes componentes curriculares que trabalhem com os conteúdos da Economia Política, da História, da Sociologia, da Filosofia, da Antropologia, entre outros tantos que, articuladamente, a partir de um intenso trabalho interdisciplinar, vão contribuindo para ampliar e alargar a visão de mundo desses educadores em formação (Molina, 2014). Portanto, a compreensão da totalidade dos processos envolvidos na relação ensino-aprendizagem se dá desde a construção de uma leitura integral dos processos sociais, econômicos, políticos, culturais envolvidos na relação educador- 
educando para um posterior refazimento do peso de cada um desses elementos nos resultados dos educandos, compreendidos, porém, como parte de uma totalidade com determinações exteriores a ela e ao que acontece em cada sala de aula, não sendo este o espaço único e central de resolução de todos os problemas dos processos de ensinoaprendizagem.

Desse modo, a formação docente nas Licenciaturas em Educação do Campo, ancorada em matrizes de base emancipatória e transformadora, sustentase no necessário debate sobre a construção pedagógica e física de escolas que sejam do campo e no campo.

A Minuta Original dos cursos estabelece que as Licenciaturas em Educação do Campo objetivem

Formar educadores para atuação na Educação Básica em Escolas do Campo aptos a fazer a gestão de processos educativos escolares e a desenvolver estratégias pedagógicas que visem a formação de sujeitos humanos autônomos e criativos capazes de produzir soluções para questões inerentes à sua realidade, vinculada à construção de um projeto de desenvolvimento sustentável de campo e de país (Molina \& Sá, 2011, p. 359).

Para que isso ocorra, a organização curricular se dá por meio da Alternância Pedagógica (Molina, Martins, \& AntunesRocha, 2021), com ênfase num perfil de educadores que se pretende formar, sendo muito importante ao argumento que se desenvolverá a seguir a compreensão de que nesse perfil de formação proposto e materializado pela LEdoC UnB estão três dimensões formativas absolutamente imbricadas e indissociáveis:

1) a docência em uma das áreas de conhecimento propostas pelo curso: Linguagens; Ciências da Natureza; Matemática. A proposta é de que cada uma das turmas ofereça aos estudantes a opção de escolha em uma destas três áreas, sendo esta definição construída entre a Universidade e suas parcerias considerando as demandas/perfil do grupo e as condições objetivas da oferta.

2) Gestão de processos educativos escolares, entendida como formação para a educação dos sujeitos nas diferentes etapas e modalidades da Educação Básica, para a construção do projeto político-pedagógico e para a organização do trabalho escolar e pedagógico nas Escolas do Campo. Ênfases: Educação Fundamental Anos Finais e Educação Básica de Nível Médio, também na Modalidade Educação de Jovens e Adultos e na combinação com a Educação Profissional.

3) Gestão de processos educativos nas comunidades: preparação específica para o trabalho formativo e organizativo com as famílias e ou grupos sociais de origem dos estudantes, para liderança de equipes e para a implementação de iniciativas e ou projetos de desenvolvimento comunitário sustentável que incluam a participação da escola (UnB, 2018, p. 43).

Além da perspectiva de práxis transformadora, foi possível perceber nas narrativas dos colaboradores 0 entendimento de que a democratização da 
gestão exige a participação efetiva da comunidade e o trabalho coletivo. A participação da comunidade é extremamente relevante para os questionamentos que se quer fazer em relação à Matriz de Competências do Diretor proposta pelo CNE. Conforme discutido anteriormente a respeito da categoria gestão democrática na perspectiva da Educação do Campo, a real participação da comunidade escolar e de todas as suas representações (professores, servidores técnico-administrativos, estudantes, pais de alunos e lideranças comunitárias camponesas) é fundamental para garantir escolas vivas, que possam responder aos anseios da realidade e da comunidade camponesa ao seu redor, fato bastante evidente no discurso de uma das colaboradoras da pesquisa.

De fato, o Projeto Político Pedagógico das Licenciaturas em Educação do Campo tem como uma de suas maiores intencionalidades formar educadores camponeses que sejam capazes de promover uma ampla vinculação das Escolas do Campo com as comunidades ao seu redor, fazendo delas verdadeiramente espaços de apoio às lutas que esses sujeitos precisam enfrentar para poderem continuar existindo e vivendo como camponeses, dadas as imensas ameaças que têm sofrido em razão do avanço muito acelerado do agronegócio sobre suas terras e territórios.

Às escolas dos territórios camponeses compete a tarefa, junto com os movimentos sociais e sindicais do campo e as universidades parceiras, de construírem estratégias de luta e resistência contra esse violento projeto de campo que, em função da insana lógica da geração incessante de lucro, foi pensado somente como espaço de negócio e não de produção e reprodução da vida. Logo, para implementar esse projeto de campo, seria preciso expulsar os sujeitos camponeses, forjando o que se denomina na Sociologia Rural de "ruralidade de espaços vazios", um campo sem sujeitos. Conforme Molina (2017, p. 597),

A transformação da forma escolar concebida no Projeto Político Pedagógico da LEdoC busca preparar um educador que seja capaz de promover, em suas práticas pedagógicas, essa constante articulação entre escola do campo e as comunidades camponesas, entre escola e vida, ou seja, entre escola e trabalho, entre estudo e produção material da vida (Freitas, 2010). Além disso, objetiva-se que o educador saiba articular as lutas cotidianamente enfrentadas pelos camponeses, decorrentes das intensas transformações na lógica de acumulação do capital no campo, e o papel da escola como mediadora nessas lutas e resistências. É necessário que esses problemas estejam presentes no cotidiano da escola, sendo ela uma produtora e socializadora de conhecimentos para 
a comunidade poder enfrentar melhor seus desafios.

Nas rodas de conversa com o egresso que ainda está na gestão (professor Adão Fernandes da Cunha) ou com as egressas que já assumiram em períodos anteriores a direção das Escolas do Campo de seus territórios (Ângela Cristina Alves e Luzinete Jesus de Oliveira Tolomeu), reafirmou-se, entre outros elementos, a importante dimensão do projeto político pedagógico da Licenciatura em Educação do Campo, que vem à tona na atuação desses profissionais na função.

Aliada a esse importante fator, revela-se também nas três falas a consciência de que esse processo não pode ser feito sozinho, que o longo caminho da transformação e da mudança exige o trabalho de grandes coletivos, tanto de estudantes quanto de educadores da própria escola, juntamente com os membros da comunidade rural onde se insere a escola com a qual se dispuseram a contribuir na condução.

Então fui para direção, passei pelo processo, e pensei estou na direção, e agora? A primeira coisa que eu aprendi na LEdoC foi o trabalho coletivo. Esse é o princípio de tudo, a gente não consegue fazer nada sozinho. A gente senta e fala assim: "olha nós temos isso, como é que a gente quer fazer? nós temos aqui e para onde que a gente quer ir, então como que a gente vai fazer? ... Eu sempre colocava a responsabilidade da gestão não era só minha, gestão democrática a gente não faz sozinho. Todos tinham que participar também do processo, das dores e das delícias desse processo. Não somente os professores, mas todo o coletivo da escola, os profissionais da limpeza, da cozinha, os técnicos que passaram a se enxergar, também, como educadores" (Ấngela Cristina Alves, Roda de Conversa).

E aí vamos nós construir esse plano e assim iniciamos um processo de gestão coletiva trabalhando qual era a prioridade naquele momento para nossa Escola Paulo Freire, para o nosso núcleo Paiol ... Nós conseguimos fazer também por esse processo, pelo conselho deliberativo, mas trazendo ainda alusão ao sujeito coletivo, participativo, também conseguimos fazer dessa forma e tem dado certo e a gestão que está longe está encaminhando e tem que seguir essa Diretriz. Começamos o processo de formação na constituição de entender a história do assentamento e aqueles professores que não fizeram parte da luta do assentamento, convidamos a mergulhar, a imergir dentro dessa história e aqueles pais também que não tinham esse entendimento, os ajudamos a passar a conhecer e aí então a formação se deu..." (Luzinete Jesus de Oliveira Tolomeu, Roda de Conversa).

... compreender o seu processo nessa sociedade como sujeito de direito, mas como sujeito coletivo de direito e que ajuda outras pessoas também se reconhecerem como sujeitos coletivos de direito e no final de tudo gente vê aí essa transformação aos poucos por mais que a gente caminha sobre passos lentos, mas são grandes ações que a gente tem conseguido. Eu acredito que a nossa direção é muito mais importante do que a velocidade com que a gente tá caminhando e a gente não para, por isso a gente continua na luta diária (Adão Ferreira da Cunha, roda de conversa). 
Nesses excertos fica demonstrado o entendimento da gestão democrática como um desdobramento da participação coletiva, que tem uma estreita relação com a luta e a resistência, muito além de uma mera administração vista apenas como técnica, mas um trabalho coletivo comprometido com a transformação das relações sociais na escola.

Um importante exemplo da promoção do trabalho coletivo na gestão pode vir da ação da gestora egressa da LEdoC Ângela Cristina Alves, à frente da Escola Ernesto Che Guevara, em Tangará da Serra, desenvolvida com base na sua compreensão crítica dos retrocessos impostos à escola pela obrigatoriedade de implementação da BNCC. A partir da compreensão da gravidade dessa Base, em termos da profunda redução do direito à educação da juventude camponesa, como relatado por ela na entrevista, desencadeou-se sob sua condução um diálogo com a comunidade escolar e com os pais dos estudantes que a frequentam, sobre a necessidade de se resistir e lutar contra a implementação da BNCC.

Falei com eles, então: 'se a gente não concorda, nós temos que apresentar outra proposta, não significa a gente não concordar e também não apresentar proposta. Nós não podemos apenas não concordar e a Escola Che Guevara ficar de braços cruzados. Nós temos que devolver uma contraproposta de vocês'. ... nós não temos que ser coniventes. ... Então, um professor falou assim: 'eu também vou à reunião para definir as ações de mobilização em relação à BNCC e acredito que todos têm que ir nessa reunião. Estão solicitando um representante, mas toda a Escola Estadual Ernesto Che Guevara repudia a BNCC, então o coletivo da Escola Che Guevara vai participar desse momento'. Então, o grupo se organizou e decidiu que todos iriam participar da referida reunião ... Ao organizar a carta (repúdio à proposta da BNCC), nós decidimos que iríamos apresentar para os alunos que estavam na Escola, ou seja, para os alunos do Ensino Médio. Então, todos foram para o refeitório e fizemos apresentação em forma de slides ... Após as várias discussões, saiu de lá o encaminhamento que, ao longo da semana, seriam desenvolvidas atividades de debate com os alunos e comunidade e, ... realizado um Manifesto na cidade. ... Então, os nossos professores também já levaram, como proposta, um dia de manifesto nas ruas. E aí estavam presentes professores de outras escolas, que têm uma discussão boa também, que estavam com essa proposta de Manifesto na rua. Nós temos que mostrar nossa cara lá (Ângela Cristina Alves, Roda de Conversa).

Esse trecho da entrevista é rico no sentido de mostrar o quanto o trabalho coletivo e a auto-organização dos professores e dos estudantes contribuem com a formação das novas gerações na perspectiva da emancipação humana. As falas dos(as) egressos(as) entrevistados(as) revelam na prática de gestão desses diretores das Escolas do Campo duas categorias fundamentais trabalhadas 
exaustivamente na materialização do PPP da LEDOC da UnB: a auto-organização (Pistrak, 2013; Krupskaya, 2017) e o trabalho coletivo (Ferreira, 2015).

Outro exemplo do coletivo da Escola Che Guevara ilustra esse argumento: tratase do Encontro da Juventude Camponesa realizado nos dias 12, 13 e 14 de novembro de 2018. Conforme expressado pela entrevistada, o processo de construção e realização do evento tornou-se uma referência de sua gestão, em função do amplo protagonismo dos estudantes da referida unidade escolar em sua construção e realização.

Envolvendo a juventude de todo o assentamento, o encontro deixou importantes marcas na comunidade assentada e escolar pela dinâmica vivenciada em sua realização, que buscou pôr em prática no movimento real da dinâmica escolar as categorias autoorganização e trabalho coletivo. Conforme relato da entrevistada e pesquisa sobre o referido período (Pereira, 2019), naquele Encontro a juventude escolar realmente protagonizou todas as tarefas, extraindo desse processo grandes aprendizados.

Com o objetivo de compreender os enormes desafios para a permanência da juventude no campo (ausência de políticas públicas que lhes garantam trabalho, renda, cultura e educação em todos os níveis), tal evento criou diferentes espaços de formação e debate, oferecendo subsídios para a compreensão crítica das contradições que envolvem o campo no país, chegando às particularidades da região Centro-Oeste e avançando na reflexão sobre quais estratégias de luta seriam necessárias ao enfrentamento da questão. De acordo com a entrevistada,

Na organização do encontro da juventude da Escola, a gente propôs que os estudantes coordenassem os momentos, não só durante o evento, mas os que antecedem. Eles já estão organizados nos grupos e precisam ver o que cada coisa pesa, ou seja, se ele está na infraestrutura, ele tem que pensar as coisas que vai ter que correr atrás. Eles têm que ter essa responsabilidade. Se estão no grupo da divulgação, por exemplo, têm que saber como irão divulgar o evento. A ideia é que sejam protagonistas, e é para isso que a gente quer contribuir. ... Não tem educador sem educando. Essa é uma via de mão dupla. A gente tem que valorizar para ser valorizado. Isso foi algo que nos ajudou a fazer o encontro da Juventude Camponesa. Foi toda essa concepção que eles tinham daquele momento de Educação. Não foi somente os professores, mas todo o coletivo da escola, dos profissionais da limpeza, da cozinha, os técnicos que passaram a se enxergar, também, como educadores ... Quando a gente organizou, pensou junto o encontro da Juventude Camponesa, quando a gente reuniu com nossos alunos e foi conversando com ele da proposta de realizar um encontro da juventude, um dos alunos perguntou: 'professora, mas por que nós vamos fazer isso?' Nós respondemos: vamos fazer isso, primeiro, para mudar um 
pouco da nossa vida. Aí ele respondeu: 'então vamos fazer sim, porque mudar a vida é o que nós estamos precisando' ... Eu falei: 'então eles também estão querendo mudar a vida deles'. Por isso, a gente tem que ter essa é atitude de puxar, ter a sensibilidade de perceber isso. $\mathrm{E}$ foi maravilhoso porque eu e Angélica, fazendo as avaliações ficamos muito emocionadas no sentido de que os jovens que ficavam no seu canto, que davam problema na escola e passaram a se destacar muito, nos momentos em que estavam envolvidos no encontro, sendo sujeitos do processo todos. $\mathrm{Na}$ hora dos agradecimentos teve um deles que ficou muito emocionado dizendo: 'eu nunca ganhei um livro professora'. Então, são coisas que vão fazendo a gente um pouco mais humana e que faz a gente pensar que estamos no caminho certo. Educação humanizadora é isso, ela tem que fazer você se sentir mais humano. Um processo que indigna, que faz movimentar para além do que está acostumado, te desafia a todo momento e te faz movimentar (Ângela Cristina Alves, Roda de Conversa).

Um outro importante marco de todos os dias de realização do evento foi realmente a presença da cultura como matriz formativa, com uma série de oficinas e apresentações dos jovens em grupos de teatro, música, capoeira, literatura e poesia. Para o objetivo deste artigo, destaca-se a importância do papel da direção da escola em perceber problemas concretos da juventude que a frequenta e, junto com ela, em buscar construir caminhos para o seu enfrentamento, entendendo que integra a função social da escola do campo a contribuição com as lutas dos camponeses para continuarem existindo como tal.

$\mathrm{Na}$ entrevista realizada em roda de conversa com a egressa da LEdoC Luzinete Jesus de Oliveira Tolomeu, que atuou como gestora da Escola Paulo Freire, no município de Cáceres, destacam-se importantes processos conduzidos por ela, baseados também nas categorias autoorganização e trabalho coletivo. A gestora relata em sua fala diferentes momentos em que foram sendo construídos avanços na Escola do Campo sob sua responsabilidade, que se espraiaram para o conjunto de dezoito Escolas do Campo da referida cidade, resultando em sua chegada à função de Coordenadora Pedagógica das Escolas do Campo do município, e posteriormente à Secretaria de Educação.

Luzinete relata que todo o processo foi conduzido com a intensa participação dos educandos e do coletivo de professores da Escola, somada à participação de muitos membros da própria comunidade do assentamento onde se localiza a Escola, que resulta da luta do Movimento dos Trabalhadores Rurais Sem Terra. Destacamos, a seguir, alguns trechos de sua entrevista que explicitam o belo processo de trabalho coletivo conduzido por ela: 
Eu assumi a direção com 100\% de aprovação, porque eu não quis ser indicada eu quis ir para eleição. Por ser indicada não precisaria, poderia assumir direto, mas eu disse: 'não, eu sou membro do assentamento, sou sujeito de dentro, sou liderança lá e não posso ser indicada pelo prefeito, porque eu não vou seguir as regras ditadas por ele. Eu trabalho para a comunidade e vamos ficar junto com a comunidade" ... Com isso iniciamos o nosso processo de gestão, eu não fui gestora sozinha, nós fomos gestores enquanto assentamento. Nesse momento que assumimos, partiu daí essa primeira formação humana que não dos educadores, dos professores que estavam na escola, mas partimos do assentamento (Luzinete Jesus de Oliveira Tolomeu, Roda de Conversa).

Esse é o contexto no qual se compreende a gestão democrática como reflexo de um processo de efetiva participação coletiva, autogestão e autoorganização dos estudantes. É um processo em que a coletividade forma um perfil de sujeito comprometido com as lutas sociais e transformação da realidade. Isso transpõe a superação da ideia de uma mera representatividade de indivíduos em órgãos colegiados, mas um efetivo envolvimento nessas instâncias.

Relevantes contribuições a esse debate têm sido sistematizadas por Dal Ri e Vieitez (2010), ao pesquisarem sobre o acúmulo pedagógico do Movimento dos Trabalhadores Rurais Sem Terra (MST), cujas práticas protagonizadas em relação à gestão democrática apontam que a participação da comunidade na direção da escola não deve ocorrer apenas numa perspectiva de democracia representativa, mas de democracia direta. As referidas autoras reafirmam nesse texto que nas escolas pesquisadas, vinculadas ao MST, materializa-se de fato uma concepção de gestão democrática na qual há efetivos espaços de vivência democrática, com real participação do poder e das decisões que efetivamente são construídas e implementadas de forma coletiva, educando-se para a democracia social.

É importante realçar que tanto a auto-organização quanto o trabalho coletivo inserem-se no PPP da Licenciatura em Educação do Campo, não só como preciosa herança teórico-prática da experiência da Pedagogia Socialista (Krupskaya, 2017; Pistrak, 2013), mas também como legado da própria Pedagogia do Movimento (Caldart, 2000) e das práticas de Educação do Campo vivenciadas já nos cursos do PRONERA (Molina, 2003, 2020).

Por auto-organização entende-se o processo de formação que cria, propõe e estimula tempos e espaços de formação nos cursos, em que os estudantes apreendam e desenvolvam a capacidade de gerir-se autonomamente, sendo capazes de pensar, conceber, planejar e executar ações coletivamente que os auxiliem na 
resolução dos problemas concretos que enfrentam. "A auto-organização deve fornecer as habilidades para resolver juntos, pelo esforço de todos, os problemas colocados pela vida" (Krupskaya, 2017, p. 132).

Nessa direção, o pensamento de Pistrak (2013, p. 121) define também que a auto-organização objetiva propiciar: “1) habilidade de trabalhar coletivamente, habilidade de encontrar seu lugar no trabalho coletivo; 2) habilidade de abraçar organizadamente cada tarefa; 3) capacidade para a criatividade organizativa". Conforme destaca o autor, o trabalho coletivo é concreto, está na tarefa do dia a dia de todos, "o trabalho vai-se constituindo como fundamento da vida nas suas várias manifestações" (Pistrak, 2013, p. 31). Por isso, compreende-se a enorme potencialidade do trabalho coletivo como possibilidade de romper com o modo de produção capitalista que individualiza 0 trabalho com base no mérito e reforça a exploração do homem pelo homem.

A análise detalhada da execução e presença dessas categorias na formação dos educadores da LEdoC UnB tem sido objeto recorrente de reflexão em teses e dissertações produzidas sobre o curso no Programa de Pós-graduação em Educação da Universidade de Brasília. A repercussão das vivências de auto-organização e do trabalho coletivo experienciados durante a formação nessa Licenciatura, seja no Tempo Universidade ou nas atividades do Curso no Tempo Comunidade, na prática pedagógica desenvolvida por egressos(as), integra as reflexões dos trabalhos de Brito (2017) e Pereira (2019), sendo ainda o objeto principal das pesquisas de R. S. Pereira (2016), Nascimento (2019) e Ferreira (2015).

As repercussões da auto-organização foram objeto específico de profunda análise no trabalho de Pereira (2013), que investigou como os tempos e espaços educativos de auto-organização e organicidade na LEdoC influíram nas mudanças organizativas no território Kalunga após o ingresso de jovens desse território no curso, com a culminância da criação de uma associação de estudantes da LEdoC no território, apontando para uma significativa recriação de espaços de representação e protagonismo no quilombo. A associação, conforme resultados da pesquisa, significou uma relevante mudança intergeracional no quilombo quanto à ocupação dos espaços coletivos de representação e organização da comunidade, com a ascensão a tais postos de muitos(as) egressos(as) da Licenciatura em Educação do Campo da UnB. O fenômeno encontrado na pesquisa vem-se mantendo com ampla inserção de 
estudantes do território no curso, que era muito pequena nas primeiras turmas, mas atualmente as turmas da LEdoC UnB são formadas majoritariamente por estudantes quilombolas Kalunga. Essa representatividade tem-se estendido muito além do curso, chegando aos espaços de poder no município. Em 2020, pela primeira vez na história de Cavalcante, um quilombola egresso da LEdoC UnB, Vilmar Kalunga, foi eleito prefeito do município. $\mathrm{Na}$ mesma eleição, três egressos da LEdoC também foram para a Câmara de Vereadores do município.

O trabalho coletivo no referido território também foi o objeto central da tese de doutorado de Ferreira (2015), que analisou as contribuições nas práticas pedagógicas de egressos(as) da LEdoC UnB no território Kalunga, concluindo que:

O trabalho coletivo é força motriz na produção de conhecimentos sobre a realidade social e para enfrentamento do contexto pedagógico/formativo e do trabalho docente na Escola do Campo e na universidade - dessa maneira, as relações de parceria e trabalho coletivo entre docência, escola e formação podem fazer avançar a organização do trabalho pedagógico, no sentido da qualidade dos processos formativos realizados no âmbito da escola, da comunidade e da universidade (p. 214).

A dissertação de Nascimento (2019) analisou as repercussões da auto- organização vivenciada na LEdoC UnB no processo de ocupação do Campus da Faculdade UnB Planaltina durante o ano de 2016, quando nacionalmente os estudantes lutavam contra a chamada "PEC da Morte", indicando que eles tiveram um papel central no processo de organização e resistência da ocupação que durou cinquenta e oito dias.

Auto-organização e trabalho coletivo são duas categorias que se fizeram muito presentes nas falas dos três entrevistados, sobre sua atuação na gestão das Escolas do Campo, e estão contidas numa outra categoria, que expressa uma das bases fundamentais da proposta de formação docente na qual se baseia o PPP da LEdoC: a compreensão da necessidade de se garantir ao futuro educador, durante seu processo de formação, uma sólida formação teórica e interdisciplinar na qual haja uma profunda e intrínseca unidade teoria-prática, que desperte nesse educador um efetivo compromisso social que lhe possibilite efetivamente internalizar a ideia do líder José Martí, de que “conhecer é transformar".

Por fim, é importante acrescentar o debate sobre a democratização da gestão na perspectiva da autogestão. Para Martins (2012), a democratização da gestão na perspectiva da Educação do Campo requer uma vinculação desse trabalho à função 
social da escola, integrando de maneira efetiva os sujeitos imbricados na realidade educacional. Nas palavras do autor, a escola gerida democraticamente pressupõe uma

... prática educativa que contribua efetivamente para o desenvolvimento das relações sociais do campo. A escola age como espaço de valorização das relações sociais e culturais dos sujeitos do campo e, mais que isso, pode funcionar como um núcleo articulador de desenvolvimento de políticas sociais de desenvolvimento local (Martins, 2012, p. 5-6).

A gestão democrática na perspectiva da Educação do Campo tem como ponto central a categoria trabalho, e é de fato democrática quando envolve, conforme Lima (2019), pelo menos duas dimensões: a) direção coletiva, ou seja, efetiva participação da comunidade nas decisões que envolvem a escola, na expectativa de um projeto de transformação social mais amplo; b) trabalho coletivo expresso na autogestão e organicidade. Essa compreensão está bem clara no excerto a seguir, no qual a participação dos envolvidos é reflexo do entendimento de que o processo coletivo se faz pela atuação dos diferentes sujeitos envolvidos no processo, formando um grande coletivo:

Educação é tudo isso, é valorizar resgatar a identidade, permitir que as pessoas que estão ao seu redor, a sua família, sua comunidade... tenham acesso aos conselhos. Que eles consigam compreender $\mathrm{o}$ seu processo nessa sociedade como sujeito de direito, como sujeito coletivo de direito e que ajuda outras pessoas também se reconhecerem como sujeitos coletivos de direito. No final de tudo, a gente vê essa transformação aos poucos, por mais que a gente caminhe sobre passos lentos, são grandes ações que a gente tem conseguido. Eu acredito que a nossa direção é muito mais importante do que a velocidade com que a gente tá caminhando e a gente não para, por isso a gente continua na luta diária (Adão Ferreira da Cunha, Dados da Pesquisa, 2021).

Isso significa que a atuação administrativo-pedagógica da comunidade escolar ultrapassa o limite da mera participação pontual em momentos esparsos, demonstra de fato a divisão do poder e controle no interior do coletivo envolvido, expressos pelas forças populares que integram a escola, além de professores, estudantes e servidores (Dal Ri; Vieitez, 2010). E a atuação dos(as) egressos(as) da LEdoC tem buscado caminhar nessa direção, envolvendo efetivamente todos os segmentos da comunidade escolar nos processos de gestão e organização do trabalho pedagógico nas escolas do campo.

É nesse sentido que a concepção de gestão democrática da LedoC UnB busca superar na prática a polissemia de tal conceito, conforme descrito no tópico específico sobre esse debate. O horizonte, 
portanto, não é somente a participação na gestão escolar, mas é a compreensão dos aprendizados e vivências na gestão democrática das escolas do campo como parte de lutas bem maiores e mais amplas do processo de construção do poder popular integrado ao projeto histórico da classe trabalhadora. Pretende-se formar educadores camponeses capazes de atuar como dirigentes e dirigidos, de protagonizar os processos de transformação da sociedade organizandose coletivamente e promovendo lutas no sentido de superação das grandes contradições da sociedade capitalista.

\section{Considerações finais}

A polissemia do conceito de gestão democrática não lhe tira a centralidade na luta dos movimentos sociais por sua presença nas Escolas do Campo, assim como na matriz das Licenciaturas em Educação do Campo tem-se como horizonte a luta pela superação da sociedade capitalista, entendendo-se como condição sine qua non para isso a superação da contradição do conflito fundamental entre capital e trabalho. Com a busca da formação dos sujeitos camponeses capazes de promover o trabalho livremente associado também na gestão democrática, surge a percepção das contradições de seu uso com diferentes focos: o limite da emancipação política ou a busca da efetiva emancipação humana.

Para não se ficar preso nessa cilada em relação ao uso do conceito de gestão democrática, tão central ao debate e às práticas da Educação do Campo, especialmente para sua proposta de construção das Escolas do Campo, é necessário se retomar aqui um dos pilares centrais do Projeto Político Pedagógico das LEdoCs, vindo da Pedagogia Socialista: a perspectiva da Escola do Trabalho.

Apresenta-se como parte do desafio desses diretores não só a compreensão das contradições centrais enfrentadas pela sociedade, mas, sobretudo o esforço coletivo em suas gestões para conseguirem organizar e promover ações que avancem no sentido de dar passos que busquem os caminhos de superação dessas contradições. Concretamente as ações passam pela construção de novas perspectivas de trabalho para a juventude camponesa, especialmente nas áreas de Reforma Agrária, com o estímulo à criação de cooperativas em que os jovens possam construir experiências de trabalho livremente associado, bem como o estímulo a experiências e práticas concretas de outras relações com a natureza com base na agroecologia e na soberania alimentar. 
Um caminho para o enfrentamento da polissemia do conceito de gestão democrática pode ser formar educadores que tenham uma sólida formação teórica interdisciplinar mediada pela práxis, capazes de promover o trabalho coletivo e de exercer a função de diretores das Escolas do Campo, entendendo as duas leis básicas do capitalismo (a exploração do homem pelo homem e a extração permanente de mais-valia) e buscando passos concretos para sua superação. As estratégias promovidas pelas gestões em questão parecem indicar caminhos significativos nessa direção.

Reafirma-se que a Matriz Nacional Comum de Competências do Diretor Escolar, disponibilizada para consulta pública, atenta contra os princípios pedagógicos que vêm sendo trabalhados nos cursos de Licenciatura em Educação do Campo no Brasil, particularmente no curso da LEdoC da Universidade de Brasília, objeto de análise deste estudo. A práxis dos(as) egressos(as) da LEdoC UnB reafirma cada vez mais que os desafios da gestão democrática estão postos, que a busca da superação da lógica capitalista, inclusive da hierarquização dos processos de gestão das escolas, apresenta-se cada vez mais desafiadora, e o caminho apresentado é o trabalho coletivo que a lógica capitalista não permite.
Conforme ressalta Caldart (2015, p. 39), constata-se a clareza de que, ao se

... mudar as relações na escola, se está mudando a sociedade. Longe disso, porque a base da mudança está em outro lugar, nas relações sociais de produção ... Mas essa é exatamente a contradição de que não podemos fugir se temos objetivos emancipatórios: ainda que saibamos que a mudança estrutural radical da escola só virá como parte de um processo revolucionário mais amplo, sem vislumbrar e desencadear processos de mudança nas relações sociais, mesmo que limitados pelas condições reais em que as práticas educativas acontecem, não há como realizar nossos objetivos educativos de desalienação para formação de lutadores e construtores (da própria revolução).

Com essa conviç̧ão, reafirma-se a importância e a necessidade de uma gestão efetivamente democrática nas Escolas do Campo e do papel do PPP das Licenciaturas em Educação do Campo na formação de educadores críticos que podem atuar na gestão com essa perspectiva. Além disso, salienta-se que o horizonte maior da Educação do Campo é o projeto educativo que objetiva contribuir com a efetiva transformação social e transformação das relações de produção na direção da superação da sociedade capitalista.

A partir da perspectiva em que se trabalha neste estudo, as ações dos(as) egressos(as) confirmam a potencialidade do PPP da LEdoC para enfrentar as 
políticas neoliberais que querem destruir a educação pública como um direito social, transformando-a em mero espaço de acúmulo de mais lucro. Por isso, é preciso cada vez mais que se formem nas Licenciaturas em Educação do Campo educadores que sejam e que atuem como lutadores e construtores do futuro (Pistrak, 2013), como desafiam os princípios da Pedagogia Socialista, e que com sua ação educativa nas Escolas do Campo também consigam promover a formação da juventude camponesa nessa direção. É fundamental cada vez mais que as forças progressistas deste país sejam articuladas para resistir às intensas investidas do capital para a transformação da educação em mercadoria, reunindo forças para mantê-la de fato como um direito público e social, e junto com esse direito, a garantia da formação crítica de educadores que possam conceber e ajudar a construir um novo projeto de sociedade em que a vida valha mais do que o lucro.

\section{Referências}

Almeida, A. W. B. (2010). Agroestratégias e desterritorialização: direitos territoriais e étnicos na mira dos estrategistas dos agronegócios. In Almeida, A. W. B., et al. (Orgs.). Capitalismo globalizado $e$ recursos territoriais: fronteiras $d a$ acumulação no Brasil contemporâneo (pp. 101-144). Rio de Janeiro: Lamparina.
ANFOPE - Associação Nacional pela Formação dos Profissionais da Educação. (2021). Boletim ANFOPE, 2(31). Recuperado de http://www.anfope.org.br/wpcontent/uploads/2021/06/BOLETIM-022021.pdf.

ANPAE - Associação Nacional de Política e Administração da Educação. (2020). Posicionamento da Associação Nacional de Política e Administração da Educação (Anpae) sobre o documento Matriz Nacional de Competências do Diretor Escolar. Recuperado de https://anpae.org.br/website/noticias/529matriz-nacional-de-competencias-dodiretor-escolar.

Ball, S. J. (2005). Profissionalismo, gerencialismo e performatividade. Cadernos de Pesquisa, 35(126), 539-564. https://doi.org/10.1590/S010015742005000300002.

Barbosa, A. I. C. (2012). A organização do trabalho pedagógico na Licenciatura em Educação do Campo/UnB: do projeto às emergências e tramas do caminhar (Tese de Doutorado). Universidade de Brasília, Brasília, DF. Recuperado de https://repositorio.unb.br/bitstream/10482/ 11286/1/2012_AnnalzabelCostaBarbosa.p df.

Bazzo, V., \& Scheibe, L. (2019). De volta para o futuro... retrocessos na atual política de formação docente. Revista Retratos da Escola, 13(27), 669-684. https://doi.org/10.22420/rde.v13i27.1038.

Beltrão, J. A., \& Tafarell, C. (2017). A ofensiva dos reformadores empresariais e a resistência de quem defende a educação pública. Revista Retratos da Escola, 11(21), 587-601. https://doi.org/10.22420/rde.v11i21.786.

Brito, M. M. B. (2017). Formação de professores na perspectiva da 
epistemologia da práxis: análise da atuação dos egressos do curso de Licenciatura em Educação do Campo da (Tese de Doutorado). Universidade de Brasília, Brasília.

Caldart, R. S. (2000). Pedagogia do Movimento Sem Terra: escola é mais do que escola. Petrópolis, RJ: Editora Vozes.

Caldart, R. S. (2011). Licenciatura em Educação do Campo e projeto formativo: qual o lugar da docência por área? In Molina, M. C., \& Sá, L. M. (Orgs.). Licenciaturas em Educação do Campo: registros e reflexões a partir das experiências-piloto (pp. 99-122). Belo Horizonte: Autêntica.

Caldart, R. S. (2015). Pedagogia do movimento e complexos de estudo. In Sapelli, M. L. S., Freitas, L. C., \& Caldart, R. S. (Orgs.). Caminhos para a transformação da escola 3 (s./p.). Organização do trabalho pedagógico nas escolas do campo: ensaios sobre complexos de estudo. São Paulo: Expressão Popular.

Chauí, M. (2014). A ideologia da competência. Belo Horizonte: Autêntica.

Constituição da República Federativa do Brasil. (1988, 5 de outubro). Recuperado de:

http://www.senado.gov.br/sf/legislacao/con st/.

Cunha, A. F. (2015). Sustentabilidade ambiental na comunidade Kalunga Vão de Almas: uma pesquisa na perspectiva ecolinguística (Monografia de Graduação). Universidade de Brasília, Planaltina.

Cunha, A. F. (2018). O calendário agrícola na Comunidade Kalunga Vão de Almas: uma proposição a partir das práticas de manejo da mandioca (Dissertação de Mestrado). Universidade de Brasília, Brasília.
Curado Silva, K. A. P. C. (2020). A (de)formação de professores na Base Nacional Comum Curricular. In Uchoa, A. M. C., Lima, Á. M., \& Sena, I. P. F. S. (Orgs.). Reformas educacionais: avanço ou precarização da educação pública? (Diálogos críticos, Vol. 2) (pp. 102-122) [Versão digital em Adobe Reader]. Recuperado de https://3c290742-53df4d6f-b12f-

6b135a606bc7.filesusr.com/ugd/48d206_b 5a8740a4b0a4ae0a58087199eefbc6a.pdf.

Dal Ri, N. M., \& Vieitez, C. G. (2010). Gestão democrática na escola pública: escola construindo o caminho. Educação Unisinos, 14(2), 111-125.

https://doi.org/10.4013/edu.2010.142.497.

Decreto n. 8.752. (2016, 10 de maio). Dispõe sobre a Política Nacional de Formação dos Profissionais da Educação Básica. Recuperado de http://www.planalto.gov.br/ccivil_03/_ato2 015-2018/2016/decreto/d8752.htm.

Ferreira, M. J. L. (2015). Docência, escola do campo e formação: qual o lugar do trabalho coletivo? (Tese de Doutorado). Universidade de Brasília. Brasília, DF. http://dx.doi.org/10.26512/2015.04.T.2006 3.

Fidalgo, N. L. R., \& Fidalgo, F. (2009). Trabalho docente e a lógica produtivista: conformação e subjetividade. In Fidalgo, F., Oliveira, M. A. M., \& Fidaldo, N. L. R. (Orgs.). A intensificação do trabalho docente: tecnologias e produtividade (pp. 91-112). Campinas, SP: Papirus.

Freitas, H. C. L. (1999). A reforma do ensino superior no campo da formação dos profissionais da educação básica: as políticas educacionais e o movimento dos educadores. Educação \& Sociedade, 20(68), 17-44. https://doi.org/10.1590/S010173301999000300002 . 
Freitas, H. C. L. (2002). Formação de professores no Brasil: 10 anos de embate entre projetos de formação. Educação \& Sociedade, 23(80), 136-167. https://doi.org/10.1590/S010173302002008000009 .

Freitas, H. C. L. (2003). Certificação docente e formação do educador: regulação e desprofissionalização. Educação \& Sociedade, 24(85), 1095-1124. https://doi.org/10.1590/S010173302003000400002 .

Freitas, H. C. L. (2004). Novas políticas de formação: da concepção negada à concepção consentida. In: Barbosa, R. L. L. (Org.). Trajetórias e perspectivas da formação de educadores (pp. 89-115). São Paulo: Editora UNESP, 2004. https://doi.org/10.7476/9788539303434.

Freitas, H. C. L. (2007). A (nova) política de formação de professores: a prioridade postergada. Educação \& Sociedade, 28(100), 1203-1230.

https://doi.org/10.1590/S0101-

73302007000300026 .

Freitas, H. C. L. (2017). Políticas educacionais em disputa e novas legislações na formação de professores (Entrevista). In 38 ${ }^{a}$ Reunião Nacional da Associação Nacional de Pós-Graduação e Pesquisa em Educação - ANPEd, Sessão Especial. São Luís, MA.

Freitas, L. C. (2011). Neotecnicismo e formação do educador. In Alves, N. (Org.). Formação de professores: pensar e fazer (pp. 95-108). São Paulo: Cortez.

Freitas, L. C. (2012). Os reformadores empresariais da educação: da desmoralização do magistério à destruição do sistema público de educação. Educação \& Sociedade, 33(119), 379-404. https://doi.org/10.1590/S010173302012000200004 .
Freitas, L. C., \& Sordi, M. R. L. (2013). Responsabilização participativa. Revista Retratos da Escola, 7(12), 87-99. https://doi.org/10.22420/rde.v7i12.263.

Freitas, L. C. (2014). Os reformadores empresariais da educação e a disputa pelo controle do processo pedagógico na escola. Educação \& Sociedade, 35(129), 10851114. $\quad$ https://doi.org/10.1590/ES010173302014143817.

Freitas, L. C. (2016). A importância da avaliação: em defesa de uma responsabilização participativa. Em Aberto, 29(96), 127-139. https://doi.org/10.24109/21766673.emaberto.29i96.3156.

Freitas, L. C. (2020). Prefácio. In Uchoa, A. M. C., Lima, A. M., \& Sena, I. P. F. S. (Org.). Reformas educacionais: avanço ou precarização da educação pública? (Diálogos críticos, Vol. 2) (pp. 9-10) [Versão digital em Adobe Reader]. Recuperado de https://3c290742-53df4d6f-b12f6b135a606bc7.filesusr.com/ugd/48d206_b 5a8740a4b0a4ae0a58087199eefbc6a.pdf.

Frigotto, G. (2009). Teoria e práxis e o antagonismo entre a formação politécnica e as relações sociais capitalistas. Trabalho, Educação e Saúde, 7(sup), 67-82. https://doi.org/10.1590/S1981-

77462009000400004.

Frigotto, G. (2016). A nova e a velha faces da crise do capital e o labirinto dos referenciais teóricos. In Frigotto, G., \& Ciavatta, M. (Orgs.). Teoria e educação no labirinto do capital (pp. 45-86). São Paulo, SP: Expressão Popular.

Gewirtz, S., \& Ball, S. J. (2011). Do modelo de gestão do "bem-estar social" ao "novo gerencialismo": mudanças discursivas sobre gestão escolar no mercado educacional. In Ball, S. J., \& 
Mainardes, J. (Orgs.). Políticas educacionais: questões e dilemas (pp. 193221). São Paulo, SP: Cortez.

Gomide, C. S., Vilas Bôas, R. L., Gudinho, M. L. M., Gouveia, L. R., \& Santos, A. L. D. (2019). Educação do Campo e Pedagogia da Alternância: experiência da UnB no sítio histórico e patrimônio cultural Kalunga. Revista Brasileira de Educação do Campo, 4, e7187. https://doi.org/10.20873/uft.rbec.e7187.

Gramsci, A. (1991). A. Os intelectuais e a organização da cultura. Rio de Janeiro: Civilização Brasileira.

Krupskaya, N. K. (2017). A tarefa educativa da escola. In Freitas, L. C., \& Caldart, R. S. (Orgs.). A construção da pedagogia socialista (escritos selecionados). São Paulo, SP: Expressão Popular.

Lei $n$. 9.394, de 20 de dezembro de 1996. (1996, 23 de dezembro). Estabelece as Diretrizes e Bases da Educação Nacional. Recuperado de http://www.senado.gov.br/sf/legislacao.

Lima, A. M. (2019). Educação, ideologia e reprodução social: notas críticas sobre os fundamentos sociais da Base Nacional Comum Curricular - BNCC. In Uchoa, A. M. C., \& Sena, I. P. F. S. (Orgs.). BNCC, educação, crise e luta de classes em pauta (Diálogos Críticos) (pp. 39-71). [Versão digital em Adobe Reader]. Recuperado de https://3c290742-53df-4d6f-b12f6b135a606bc7.filesusr.com/ugd/48d206_e bfad3afbe96442880041cceed90e5e6.pdf.

Lima, A. M., \& Sena, I. P. F. S. (2020). A pedagogia das competências na BNCC e na proposta da BNC de formação de professores: a grande cartada para uma adaptação massiva da educação à ideologia do capital. In Uchoa, A. M. C., Lima, Á. M., \& Sena, I. P. F. S. (Orgs.). Reformas educacionais: avanço ou precarização da educação pública? (Diálogos Críticos, Vol. 2) (pp. 11-37) [Versão digital em Adobe Reader]. Recuperado de https://3c290742-53df-4d6f-b12f6b135a606bc7.filesusr.com/ugd/48d206_b 5a8740a4b0a4ae0a58087199eefbc6a.pdf.

Martins, F. J. (2012). Gestão democrática e educação do campo. Revista Brasileira de Política e Administração da Educação, 28(1), 112-128. https://doi.org/10.21573/vol28n12012.361 $\underline{45}$.

Mészáros, I. (2008). A educação para além do capital. (2a ed.). São Paulo: Boitempo.

Minuta de Projeto de Resolução MEC/CNE. (2021). Institui Matriz Nacional Comum de Competências do Diretor Escolar, para Gestão de Qualidade da Educação. Processos n. 23000.030224/2020-01 e 23001.000018/2006-09. Recuperado de http://portal.mec.gov.br/index.php?option= com_docman\&view $=$ download\&alias $=172$ 851-parecer-resolucao-cne-matrizcompetencias-diretor-escolar2\&category_slug=marco-2021pdf\&Itemid=30192.

Molina, M. C. (2003). A contribuição do PRONERA na construção de políticas públicas de Educação do Campo e desenvolvimento sustentável (Tese de Doutorado). Universidade de Brasília. Brasília.

Molina, M. C., \& SÁ, L. M. (2011). A Licenciatura em Educação do Campo da Universidade de Brasília: estratégias político-pedagógicas na formação de educadores do campo. In Molina, M. C., \& Sá, L. M. (Orgs.). Licenciaturas em Educação do Campo: registros e reflexões a partir das experiências-piloto (UFMG; UnB; UFBA e UFS) (pp. 35-62). Belo Horizonte, MG: Autêntica. 
Molina, M. C. (2012). Políticas pública. In Caldart, R. S. et al. (Orgs.). Dicionário da Educação do Campo (pp. 587-596). São Paulo: Expressão Popular.

Molina, M. C., \& Sá, L. M. (2012). Escola do campo. In Caldart, R. S. et al. (Orgs.). Dicionário da Educação do Campo (pp. 326-333). São Paulo: Expressão Popular.

Molina, M. C. (2015). Expansão das Licenciaturas em Educação do Campo: desafios e potencialidades. Educar em Revista, (55), 145-166. https://doi.org/10.1590/0104-4060.39849.

Molina, M. C., \& Hage, S. M. (2015). Política de formação de educadores do campo no contexto da expansão da educação superior. Revista Educação em Questão, 121-146. https://doi.org/10.21680/1981$\underline{1802.2015 v 51 n 37 I D 7174 .}$

Molina, M. C. (2017). Contribuições das Licenciaturas em Educação do Campo para as políticas de formação de educadores. Educação \& Sociedade, 38(140), 587-609. DOI: $\quad$ https://doi.org/10.1590/es010173302017181170.

Molina, M. C., Antunes-Rocha, M. I., \& Martins, M. F. A. (2019). A produção do conhecimento na Licenciatura em Educação do Campo: desafios e possibilidades para o fortalecimento da educação do campo. Revista Brasileira de Educação, 24, e240051, 1-30. https://doi.org/10.1590/S141324782019240051.

Molina, M. C., \& Pereira, M. F. R. (2019). A práxis como categoria estruturante do projeto de transformação na forma da escola do campo. In Anais $39^{a}$ reunião da ANPED.

Molina, M. C. (2020). Panorama das Licenciaturas em Educação do Campo nas IFES no Brasil. In Ruas, J. J., Brasil, A., \&
Silva, C. (Orgs.). Educação do Campo: diversidade cultural, socioterritorial, lutas e práticas (pp. 85-100). Campinas, SP: Pontes Editores.

Molina, M. C., Santos, C. A., \& Brito, M. M. B. (2020). O Pronera e a produção do conhecimento na formação de educadores e nas ciências agrárias: teoria e prática no enfrentamento ao bolsonarismo (Dossiê: Consequências do bolsonarismo sobre os direitos humanos, a educação superior e a produção científica no Brasil). Revista Eletrônica de Educação, (14), 1-25, e4539138.

https://doi.org/10.14244/198271994539.

Molina, M. C., Martins, M. F. A., \& Antunes-Rocha, M. I. (2021). Formação em Alternância nos cursos de Licenciatura em Educação do Campo desenvolvidos na UnB e na UFMG: articulando universidade, campo e escola numa perspectiva socioterritorial. Revista Brasileira de Educação, 6, e11856. http://dx.doi.org/10.20873/uft.rbec.e11856.

Nascimento, T. A. (2019). Educação de jovens e adultos e extensão universitária: $a$ Licenciatura em Educação do Campo da UnB e a experiência com a Educação Popular (Dissertação de Mestrado). Universidade de Brasília. Brasília.

Neves, L. M. W. (2005). A sociedade civil como espaço estratégico de difusão da nova pedagogia da hegemonia. In Neves, L. M. W. (Org.). A nova pedagogia da hegemonia: estratégias do capital para educar o consenso (pp. 85-125). São Paulo: Xamã.

Parecer MEC/CNE/CEB n. 36/2001. (2002, 13 de março). Diretrizes Operacionais para a Educação Básica nas Escolas do Campo. Recuperado de http://portal.mec.gov.br/index.php?option= com_docman\&view=download\&alias $=119$ 89-pceb036-01- 
pdf\&category_slug=novembro-2012pdf\&Itemid=30192.

Paula, H. V. C. (2020). Territórios e projetos em disputa na institucionalização dos cursos de licenciatura em educação do campo (Tese de Doutorado). Universidade Federal de Uberlândia. Uberlândia. http://doi.org/10.14393/ufu.te.2020.3609.

Pereira, E. N. (2013). A prática educativa e as contribuições do processo formativo da organicidade da Licenciatura em Educação do Campo da UnB: um estudo de caso no território Kalunga/Goiás (Dissertação de Mestrado). Universidade de Brasília, Brasília.

Pereira, M. F. R. (2019). A licenciatura em educação do campo da UnB e a práxis docente na transformação da forma escolar a partir da atuação de suas egressas (Tese de Doutorado). Universidade de Brasília. Brasília. Recuperado de https://repositorio.unb.br/handle/10482/35 $\underline{820}$.

Pereira, R. S. (2016). A política de competências e habilidades na educação básica pública: relações entre Brasil $e$ OCDE (Tese de Doutorado). Universidade de Brasília, Brasília. Recuperado de https://repositorio.unb.br/bitstream/10482/ 22756/3/2016_RodrigodaSilvaPereira.pdf.

Pistrak, M. M. (2013). A escola-comuna. São Paulo, SP: Expressão Popular.

Pistrak, M. M. (2018). A auto-organização dos estudantes. In Pistrak, M. M. Fundamentos da escola do trabalho (pp. 221-280). São Paulo, SP: Expressão Popular.

Praciano, J. B. A., \& Feitosa, R. A. (2020). Auto-organização da Escola do Trabalho em Krupskaya e Pistrak: análise inicial sobre a autogestão estudantil a partir da experiência pedagógica soviética.
Germinal: Marxismo e Educação em Debate, 12(1), 244-259. https://doi.org/10.9771/gmed.v12i1.36838.

Ravitch, D. (2011). Vida e morte do grande sistema escolar americano: como os testes padronizados e o modelo de mercado ameaçam a educação. Porto Alegre, RS: Sulina.

Resolução MEC/CNE/CP n. 2. (2015, $1^{\circ}$ de julho). Define as Diretrizes Curriculares Nacionais para a formação inicial em nível superior (cursos de licenciatura, cursos de formação pedagógica para graduados e cursos de segunda licenciatura) e para a formação continuada. Recuperado de http://portal.mec.gov.br/docman/agosto2017-pdf/70431-res-cne-cp-00203072015-pdf/file.

Schlesener, A. H. (2019). "Esta mesa redonda é quadrada": a gestão democrática no contexto da democracia burguesa. Práxis Educativa, 14(1), 362-376. https://doi.org/10.5212/PraxEduc.v.14n1.0 19 .

Sena, I. P. F. S. (2019a). A BNCC, a luta de classes e a educação no campo. Cruz das Almas, BA: Ed. Universidade Federal do Recôncavo da Bahia.

Sena, I. P. F. S. (2019b). Convite ao questionamento e à resistência ao abismo lançado pela Base Nacional Comum Curricular - BNCC. In Uchoa, A. M. C., \& Sena, I. P. F. S. (Orgs.). BNCC, educação, crise e luta de classes em pauta (Diálogos Críticos) (pp. 15-38). [Versão digital em Adobe Reader]. Recuperado de https://3c290742-53df-4d6f-b12f6b135a606bc7.filesusr.com/ugd/48d206_e bfad3afbe96442880041cceed90e5e6.pdf.

Shiroma, E. O., Garcia, R. M. C., \& Campos, R. F. (2011). Conversão das "almas" pela liturgia da palavra: uma análise do discurso do movimento Todos pela Educação. In Ball, S. J., \& Mainardes, 
J. (Orgs.). Políticas educacionais: questões e dilemas (pp. 222-248). São Paulo, SP: Cortez.

Sidou, A. M. O., Jimenez, S. V., \& Gomes, V. C. (2014). Dos princípios da administração escolar ao paradigma da gestão democrática: um estudo fundado na crítica marxista. Revista Cadernos de Estudos e Pesquisas do Sertão, 2(1), 66$79 . \quad$ Recuperado de http://seer.uece.br/?journal=cadernospesqu isadosertao\&page $=$ article\&op=view\&path \%5B\%5D=2824\&path\%5B\%5D=2292.

Silva, A. G. (2019). Cultura como matriz formativa na Licenciatura em Educação do Campo da UnB: potencialidades do trabalho com o teatro político e o vídeo popular (Dissertação de Mestrado). Universidade de Brasília, Brasília.

Silva, H. S. A., Anjos, M. P., Molina, M. C., \& Hage, S. A. M. (2020). Formação de professores do campo frente às "novas/velhas" políticas implementadas no Brasil: r-existência em debate (Dossiê: Consequências do bolsonarismo sobre os direitos humanos, a educação superior e a produção científica no Brasil). Revista Eletrônica de Educação, 14, 1-25, e4562146.

https://doi.org/10.14244/198271994562.

Silva, L. M. M., \& Gehrke, M. (2018). Pedagogia socialista soviética: categorias que se articulam na construção de uma nova escola para uma nova sociedade. Revista Educere et Educare, 13(30). https://doi.org/10.17648/educare.v13i30.19 $\underline{584 .}$

Souza, A. G., \& Brick, E. M. (2017). Ensino de Ciências da Natureza e Matemática a partir da realidade do Assentamento Antônio Conselheiro, Tangará da Serra/MT: reflexões sobre uma prática de Educação do Campo inspirada na perspectiva freiriana. In Molina, M. C. (Org.). Licenciaturas em Educação do
Campo e o ensino de Ciências Naturais: desafios à promoção do trabalho docente interdisciplinar (pp. 25-75). Brasília, DF: Ed. Universidade de Brasília.

Tardin, J. M., \& Guhur, D. M. P. (2017). Agroecologia: uma contribuição camponesa à emancipação humana e à restauração revolucionária da relação metabólica sociedade-natureza. In Molina, M. C., Michelotti, F., Villas Boas, R. L., \& Fagundes, R. (Orgs.). Análise de Práticas contra-hegemônicas na formação dos profissionais de Ciências Agrárias: reflexões sobre o Programa Residência Agrária. Vol. II (pp. 44-99). Brasília, DF: Ed. Universidade de Brasília.

UnB (Universidade de Brasília). (2018). Projeto Político Pedagógico do Curso de Licenciatura em Educação do Campo. Faculdade UnB Planaltina (FUP), Planaltina, DF. Recuperado de http://fup.unb.br/wpcontent/uploads/2019/02/PPC_-Educacaodo-Campo-Em-implementacao.pdf.

Unesco (2018). Activating Policy Levers for Education 2030: the untapped potential of governance, school leadership, and monitoring and evaluation policies. Recuperado de https://teachertaskforce.org/knowledgehub/activating-policy-levers-education2030-untapped-potential-governanceschool.

Informações do Artigo / Article Information

Recebido em : 30/08/2021

Aprovado em: 12/10/2021

Publicado em: 13/11/2021

Received on August 30th, 2021

Accepted on October 12th, 2021

Published on November, 13th, 2021

Contribuições no Artigo: Os(as) autores(as) foram os(as) responsáveis por todas as etapas e resultados da pesquisa, a saber: elaboração, análise e interpretação dos dados; escrita e revisão do conteúdo do manuscrito 
e; aprovação da versão final publicada.

Author Contributions: The author were responsible for the designing, delineating, analyzing and interpreting the data, production of the manuscript, critical revision of the content and approval of the final version published.

Conflitos de Interesse: Os(as) autores(as) declararam não haver nenhum conflito de interesse referente a este artigo.

Conflict of Interest: None reported.

\section{Avaliação do artigo}

Artigo avaliado por pares.

\section{Article Peer Review}

Double review.

\section{Agência de Fomento}

Não tem.

\section{Funding}

No funding.

\section{Como citar este artigo / How to cite this article}

\section{APA}

Molina, M. C., Pereira, M. F. R., \& Brito, M. M. B. (2021). A práxis de egressos(as) da LEdoC UnB na gestão das escolas do campo: caminhos para resistência à Matriz Nacional Comum de Competências do Diretor Escolar.

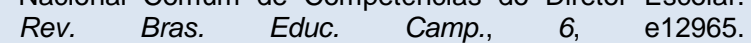
http://dx.doi.org/10.20873/uft.rbec.e12965

\section{ABNT}

MOLINA, M. C.; PEREIRA, M. F. R.; BRITO, M. M. B. A práxis de egressos(as) da LEdoC UnB na gestão das escolas do campo: caminhos para resistência à Matriz Nacional Comum de Competências do Diretor Escolar. Rev. Bras. Educ. Camp., Tocantinópolis, v. 6, e12965, 2021. http://dx.doi.org/10.20873/uft.rbec.e12965 